\title{
Quaternary glaciation of Mount Everest
}

\author{
Lewis A. Owen ${ }^{a *}$, Ruth Robinson ${ }^{\mathrm{b}}$, Douglas I. Benn ${ }^{\mathrm{b}, \mathrm{c}}$, Robert C. Finkel ${ }^{\mathrm{d}}$, Nicole K. \\ Davis $^{\text {a }}$, Chaolu Yi ${ }^{\mathrm{e}}$, Jaakko Putkonen ${ }^{\mathrm{f}}$, Dewen Li ${ }^{\mathrm{g}}$, Andrew S. Murray ${ }^{\mathrm{h}}$ \\ ${ }^{a}$ Department of Geology, University of Cincinnati, Cincinnati, OH 45221, USA \\ ${ }^{b}$ School of Geography and Geosciences, University of St. Andrews, St. Andrews, KY16 9AL, UK \\ ${ }^{c}$ Department of Geology, University Centre in Svalbard, N-9171 Longyearbyen, Norway \\ ${ }^{d}$ Department of Earth and Planetary Sciences, University of California, Berkeley, CA 95064 USA and \\ Centre Européen de Recherche et d'Enseignement des Géosciences de l'Environnement, 13545 Aix en \\ Provence Cedex 4 France \\ ${ }^{e}$ Institute for Tibetan Plateau Research, Chinese Academy of Sciences, Beijing, 100085, China \\ ${ }^{f}$ Department of Geology and Geological Engineering, 81 Cornell St. - Stop 8358, University of \\ North Dakota, Grand Forks, ND 58202-8358 USA \\ ${ }^{g}$ _China Earthquake Disaster Prevention Center, Beijing, 100029,China \\ ${ }^{h}$ Nordic Laboratory for Luminescence Dating, Department of Earth Sciences, University of \\ Aarhus, Risø DTU, DK 4000 Roskilde, Denmark
}

\begin{abstract}
The Quaternary glacial history of the Rongbuk valley on the northern slopes of Mount Everest is examined using field mapping, geomorphic and sedimentological methods, and optically stimulated luminescence (OSL) and ${ }^{10} \mathrm{Be}$ terrestrial cosmogenic nuclide (TCN) dating. Six major sets of moraines are present representing significant glacier advances or still-stands. These date to $>330 \mathrm{ka}$ (Tingri moraine), $>41 \mathrm{ka}$ (Dzakar moraine), 24-27 ka (Jilong Moraine), 14-17 ka (Rongbuk moraine), 8-2 ka (Samdupo moraines) and $\sim 1.6 \mathrm{ka}$ (Xarlungnama moraine). The Samdupo glacial stage is subdivided into Samdupo I (6.8-7.7 ka) and Samdupo II ( 2.4 ka). Comparison with OSL and TCN defined ages on moraines on the southern slopes of Mount Everest in the Khumbu Himal show that glaciations across the Everest massif were broadly
\end{abstract}

\footnotetext{
* Corresponding author. Fax: +1 5135564203.

E-mail address: Lewis.Owen@uc.edu (L.A. Owen)
} 
synchronous. However, unlike the Khumbu Himal, no early Holocene glacier advance is recognized in the Rongbuk valley. This suggests that the Khumbu Himal may have received increased monsoon precipitation in the early Holocene to help increase positive glacier mass balances, while the Rongbuk valley was too sheltered to receive monsoon moisture during this time and glaciers could not advance. Comparison of equilibrium-line altitude depressions for glacial stages across Mount Everest reveals asymmetric patterns of glacier retreat that likely reflects greater glacier sensitivity to climate change on the northern slopes, possibly due to precipitation starvation.

Keywords: Mount Everest; Himalaya; Tibet; glacial geology; terrestrial cosmogenic surface exposure dating; luminescence dating 


\section{Introduction}

Mount Everest (Sagarmatha (Nepal), Qomolongma Shan (Tibet)) is the world's highest peak (8848 $\mathrm{m}$ asl [above sea level]). Yet, despite the fascination for Mount Everest and its neighboring peaks, the style and timing of glaciation across these mountains has not been adequately defined. Most previous studies have concentrated on the south slopes of Mount Everest and have included geomorphic mapping, and relative, radiocarbon, optically stimulated luminescence (OSL) and terrestrial cosmogenic nuclide (TCN) surface exposure dating (Benedict, 1976; Iwata, 1976; Fushimi, 1977, 1978; Müller, 1980; van Williams, 1983; Richards et al., 2000b; Finkel et al., 2003; Barnard et al., 2006). In contrast, research on the northern slopes has been limited to geomorphic mapping, relative weathering studies and very limited radiocarbon dating (van Williams, 1983; Zheng, 1988; Burbank and Kang, 1991; Mann et al., 1996). To reconstruct the patterns and timing of glaciation across Mount Everest, and in particular to assess whether glaciation was synchronous between the northern and southern slopes, and to compare their equilibrium-line altitudes, we examined the glacial geology of the Rongbuk valley on the northern slopes of Mount Everest and compared our findings with our previous studies in the Khumbu Himal on the southern slopes of Mount Everest (Richards et al. 2000b; Finkel et al., 2003).

\section{Study Area}

Mount Everest is located toward the eastern end of the Himalaya astride the border of Nepal and

Tibet (Fig. 1). Our previous research focused on the glacial successions along the Imja Khola from 
Thyangboche to the Chhukung and the Khumbu Glaciers in the Khumbu Himal of Nepal (Richards et al. 2000b; Finkel et al., 2003). In this study we focus our efforts on northern slopes of Mount Everest from the snout of the Rongbuk Glacier at $5200 \mathrm{~m}$ asl down the Rongbuk valley to $\sim 4800 \mathrm{~m}$ asl.

Mount Everest is influenced by two dominant climate systems, the mid-latitude westerlies and the south Asian monsoon. Benn and Owen (1998) suggested that glaciation throughout the region was forced to differing degrees by variations in these climate systems and that glaciation throughout the Himalaya and Tibet may consequently be asynchronous. The climate in the Rongbuk valley is semi-arid and cold. However, contemporary climatic data for the Rongbuk valley on the northern slopes of Mount Everest is sparse. The mean annual precipitation during 1959 at the Rongbuk monastery (5030 m asl) was $335 \mathrm{~mm}$, whereas $790 \mathrm{~mm}$ water equivalent fell annually between 1966 and 1969 at an altitude of $5900 \mathrm{~m}$ asl on the Rongbuk Glacier (Lanchow Institute, 1975, cited in Mann et al., 1996). The mean annual temperature at the Rongbuk monastery was $0.5^{\circ} \mathrm{C}$ in 1959 (Lanchow Institute, 1975, cited in Mann et al., 1996). Huang (1990) estimated the mean annual temperature as $-6.5^{\circ} \mathrm{C}$ at an altitude of $5400 \mathrm{~m}$ on the Rongbuk Glacier. Mann et al. (1996) suggest that the monthly mean air temperatures above an altitude of $5000 \mathrm{~m}$ asl in the Rongbuk valley are probably below freezing, except between June and September, when, under the influence the result of the south Asian summer monsoon, most of the annual precipitation falls in Tibet. The glaciers on the northern slopes of Mount Everest are polythermal with basal melting 
occurring only under parts of the ablation zone (Huang, 1990; Mann et al., 1996). Vegetation in the Rongbuk valley is sparse and limited to small scrubs, grasses and moss. The bedrock geology is dominated by Ordovician siltstone, sandstone, limestone, and marble, and Late Precambrian greenschists, and these are intruded by Miocene mylonitic leucogranite. The geology is described in detail by Burchfield et al. (1992), Searle (2003) and Law (2004).

The earliest geochronological studies of Mount Everest involved radiocarbon dating of Late Holocene moraines in the Khumbu Himal (Benedict, 1976; Fushimi, 1978; Müller, 1980). This was followed by OSL dating of Late Quaternary moraines in the Khumbu Himal by Richards et al. (2000b), who showed that glaciers advanced during the global Last Glacial Maximum (LGM; 19$23 \mathrm{ka}$ at Chronozone level 1 or 18-24 ka at Chronozone level 2 of Mix et al., 2001), the early Holocene ( $\sim 10 \mathrm{ka})$, and the Late Holocene (1-2 ka). The timing of these advances was confirmed by Finkel et al. (2003) using ${ }^{10} \mathrm{Be}$ TCN dating methods. Finkel et al. (2003) were also able to define the ages of a Neoglacial advance at $~ 3.6 \mathrm{ka}$, a Late Glacial advance (15-16 ka), and two advances during marine oxygen isotope stage (MIS) 3. A summary of the chronology is provided in Table 1.

Five sets of moraines, referred to herein as the Xarlungnama (youngest), Samdupo, Rongpudoi, Rongbuk and Jilong moraines, have been identified in the Rongbuk valley by previous workers (Pison et al., 1986; Zheng, 1989; Burbank and Kang, 1991; Mann et al., 1996: Table 2). The 
Xarlungnama moraines consist of three end moraines within $300 \mathrm{~m}$ of the ice terminus, all above $5150 \mathrm{~m}$ asl. The Samdupo moraines include two sets of several sharp-crested end moraines enclosing hummocky deposits at $\sim 3 \mathrm{~km}$ from the glacier snout, in the area of the lowest Everest base camp at $\sim 5100 \mathrm{~m}$ asl. These were referred to as the Rongbude and Tongqoing moraines by Zheng (1989). The Rongpudoi moraines are prominent lateral moraines on the western valley wall. Two lateral moraines are especially well-preserved in the area $\sim 3-4 \mathrm{~km}$ north of the modern glacier terminus. Farther downvalley, the deposits are modified by post-glacial slope processes. The geomorphology of the Rongbuk end moraine is best preserved on the east side of the road north of the Rongbuk monastery. In the subsurface, the moraine may extend to the west side of the road, where glacial sediment has been buried by a landslide. In the Jilong area on the eastern valley wall, a series of denuded ridges and concentrated zones of very large surface boulders have been interpreted as glaciofluvial terraces, lateral moraines, or a combination of the two (Zheng, 1989; Burbank and Kang, 1991; Mann et al., 1996). Boulder deposits that run obliquely across-slope are also visible across the river at a comparable elevation. Therefore we interpret these as lateral moraines. In addition to these moraines, we identified an older set of moraines north of the Jilong moraines, which we refer to as the Dzakar moraines. Scattered erratics and glacially eroded bedrock are present at altitudes above $5200 \mathrm{~m}$ asl south of Rongbuk, which we have called the Tingri moraines.

Three geochronologic classification schemes have been proposed for the Rongbuk valley by 
previous workers using a series of relative dating techniques, correlation with other glaciated valleys in the Himalaya and with global climate records (Pison et al., 1986; Kuhle, 1987, 1988; Zheng, 1989; Burbank and Kang, 1991; Mann et al., 1996; Table 2). The proposed geochronologies differ significantly, with the inferred age for the oldest moraines ranging from Late Pleistocene (Zheng, 1989) to Middle Pleistocene (Burbank and Kang, 1991). These are summarized in Table 2.

Pison et al. (1986) distinguished multiple sets of moraines in the Rongbuk valley and developed the first significant morphostratigraphy, numbering the moraines G1 through G5. They argued that the oldest and most extensive glaciations (G5) extend just beyond Chedung where the Dzakar Chu valley begins to narrow and they called this the Chedung stage. They assigned an impressive moraine near the Rongbuk monastery and associated landforms to the Rongbuk stage (G4) and argued that this formed during the Late Glacial. Two sets of moraines near Song Duo Po were assigned to the Song Duo Po stage (G2 and G3), which they believed formed during the Neoglacial. In addition, moraines near the contemporary glaciers were assigned to G1 and were believed to have formed during and after the Little Ice Age.

Kuhle (1988) described the succession of moraines in the Rongbuk valley, numbering them I to X and assigned them to the Little Ice Age (X-VIII), recent Dhaulagiri stage (VII), older Dhaulagiri stage (VI), Nauri stage (V), Sirkung stage (IV), Dhampu stage (III), Taglung stage (II) and Ghasa 
stage (I). Kuhle (1988) argues that an extensive ice sheet existed across Tibet and advanced across the Himalaya during the Ghasa stage, and that the Taglung and Dhampu stage moraines represent recessional moraines of the ice sheet. Kuhle (2005) continued by arguing that the region had continuous ice-capped areas that were part of the southern continuation of his proposed inland ice sheet for central Tibet despite abundant evidence that shows an ice sheet could not have existed over Tibet during the last few glacial cycles (see Lehmkuhl and Owen, 2005, Seong et al., 2008).

Zheng (1989) identified three glacial stages in the Rongbuk valley: the Little Ice Age; Late Holocene (Neoglacial); and Late Pleistocene (Table 2). Ages were inferred based on a field investigation of the geomorphology, sedimentology, and correlations based on glacial chronologies in other parts of the Himalaya. Multiple advances were identified within each of the three glacial stages. In this classification scheme, moraines near the Rongbuk and Jilong monasteries were considered separate advances of the same Late Pleistocene glaciation.

Burbank and Kang (1991) examined the relative weathering characteristics of boulders on moraine crests and concluded that the Rongpudoi moraines were deposited during three separate Pleistocene ice advances (Table 2; Fig. 2). The lowest ridge was correlated with MIS 2 and assigned an age of $18 \mathrm{ka}$. The middle and upper Rongpudoi moraines were correlated with MIS 6 or 4 and MIS 10 or 8, respectively. Burbank and Kang (1991) acknowledge that the age estimates vary greatly and depend on the assumptions used. The Rongbuk glaciation was correlated with 
MIS 6 because boulders on the Rongbuk end moraine showed the most similarity to those on the middle Rongpudoi moraine. Burbank and Kang (1991) agreed with Zheng (1989) that the Samdupo moraines are Neoglacial, but they did not study the Jilong or Xarlungnama moraines directly.

Mann et al. (1996) used lichenometry, soil development, statistical analyses of boulder weathering data, and minimum limiting radiocarbon ages to distinguish moraines of different ages as the Little Ice Age (Xarlungnama moraine), mid- or Late Holocene (Samdupo moraine), pre-Late Holocene (Rongbuk moraine), and pre-Holocene (Higher Rongpudoi moraine). The Upper Rongpudoi moraine was correlated with the Rongbuk moraine, and these were tentatively assigned to the LGM. Age assignments based on radiocarbon dating of carbonate coats on cobbles buried in moraine sediment and peat from a spring provided the first absolute ages obtained for glacial deposits in the Rongbuk valley, although these ages may significantly underestimate the true age of the moraines since the precipitation of carbonate may occur a long time after moraine formation. The Jilong moraine, therefore, is probably much older than its minimum limiting radiocarbon age of 3170 \pm 70 C-14 years BP ( 3385 \pm 65 Cal years BP; Mann et al., 1996).

Recent chronologies suggest that glaciers in the Himalaya do not respond solely to temperature changes. In fact, some of the major ice advances in the Himalaya may have occurred during times of low latitude insolation maxima when global temperature was relatively warm but the south 
Asian summer monsoon was delivering abundant snow at high elevations (e.g., Finkel et al., 2003). In addition, significant regional asynchroneity has been detected in the timing of Himalayan glaciations, probably as a result of variation in local and regional climate and topographic variables. Therefore, it is hazardous to assign/correlate moraines directly with climatostratigraphic times without the application of numerical dating. Some of the chronologies in other parts of the Himalaya that were used by previous workers to infer ages for deposits in the Rongbuk valley have themselves been revised using these techniques (cf. Finkel et al., 2003; Lehmkuhl and Owen, 2005; Owen et al., 2008). The glacial deposits in the Rongbuk valley have been dated primarily by correlation with global climate records and with other sites in the Himalaya, and therefore, it is important to apply new quantitative geochronologic tools such as TCN surface exposure and OSL dating to provide a quantitative estimate of the timing of glaciation in this area.

\section{Methods}

\section{1. Field methods}

The geomorphology of the Rongbuk valley was investigated along the Dzakar Chu (river) from the terminus of the debris-covered Rongbuk Glacier to the Jilong monastery in the north. Glacial and associated landforms were mapped in the field aided by the interpretation of Google Earth and ASTER imagery (Fig. 2).

\subsection{Sampling for OSL dating}


Samples for OSL dating were collected from fluvioglacial and supraglacially derived sand deposits associated with, and within end and lateral moraines (Figs. 3 and 4) and sedimentary logs were drawn for each sample locality. Although the moraine sediments are dominated by mass movement (debris-flow and rock-fall) deposits, the deposits contained sufficient dm-thick lenses of sorted fine-medium and medium-coarse sand with planar- and ripple-cross lamination $(<2 \mathrm{~cm}$ in height) and normal grading on a cm scale (Figs. 3 and 4). Samples were collected from the fine- and medium-grained sand deposits as these sediments are more likely exposed to light during transport and deposition, and should have less residual luminescence at the time of deposition than samples collected from mass flow deposits. This "bleaching" of sediment is required prior to burial in order that the observed luminescence signal is related to the accumulated radiation dose since burial, and thus the time since burial (e.g., Murray and Olley, 2002). The problems associated with dating glaciogenic sediments with luminescence methods are discussed in more detail in Richards (2000) and Fuchs and Owen (2008).

The sampled sands comprise three main facies: thin (several $\mathrm{cm}$ thick), laterally discontinuous (sub-metre) lenticular fine-medium or medium-coarse moderately sorted arkosic sand units that fine-upwards on a $\mathrm{cm}$ scale and may contain ripple or flat cross-lamination; more continuous (several metres) stacked thinly bedded fine-medium sands with abundant ripple cross lamination that fine upwards over several $\mathrm{cms}$; and several cm-thick massive fine-grained silt deposits. Samples were collected in 3-4 cm diameter and $15 \mathrm{~cm}$ long black PVC tubes. One end of the tube 
was taped and the open end was tapped into a cleaned exposure face until the tube was full of sediment. The tube was extracted and taped immediately, and placed in an opaque plastic bag to reduce moisture loss. Environmental radiation (U, Th and $\mathrm{K}$ concentrations) was measured in situ for 30 minutes per sample using an EG\&G ORTEC MicroNOMAD gamma spectrometer.

\subsection{Sampling for ${ }^{10}$ Be TCN dating}

Samples for ${ }^{10} \mathrm{Be}$ TCN surface exposure dating were collected from the surface of the Rongbuk Glacier, moraines, an outwash terrace and a large landslide within the Rongbuk valley (Figs. 3, 5 to 8 ). We noted the geomorphic characteristics of the boulders, moraines, and the sample sites that might indicate post-depositional modification of the exposed surface, including the size of the boulder, the degree and nature of the surface (i.e. weathering or glacial polish), and the degree of burial within the sediment. We also recorded the lithology, thickness of the sample, topographic shielding, and if applicable, the dip of the sample surface.

\subsection{Laboratory methods for OSL dating}

Standard preparation techniques were employed in the laboratory as described in Spencer and Owen (2004) and Robinson et al. (2005), and are described in detail in the data repository item.

\subsection{Laboratory methods for TCN dating}

Samples were prepared using the methods described in Dortch et al. (2009) and specific details are 
outlined in the data repository item. All ${ }^{10} \mathrm{Be} \mathrm{TCN}$ ages for boulder samples were calculated by applying the Lal (1991) and Stone (2000) time independent model using the CRONUS Earth 2 calculator (Balco et al., 2008; http://hess.ess.washington.edu/math/; Table 4). Samples Ron-46 to Ron-50 were used to calculate boulder erosion rates using the methods of Lal (1990) to provide a weighted mean erosion rate that varies between 1.5 and $5.1 \mathrm{~m} / \mathrm{Ma}$ with a weighted mean of 2.5 m/Ma. The ${ }^{10} \mathrm{Be}$ TCN ages of Finkel et al. (2003) for the Khumbu Himal were recalculated using the CRONUS Earth 2 calculator with a zero boulder erosion rate. Erosion rates of $2.5 \mathrm{~m} / \mathrm{Ma}$ would cause the $0 \mathrm{~m} / \mathrm{Ma}$ ages given in the table to underestimate an age at $1 \mathrm{ka}$ age by $<0.5 \%, 10 \mathrm{ka}$ age by $\sim 2 \%, 20$ ka age by $\sim 5 \%, 40$ ka age by $\sim 10 \%$, and 100 ka by $\sim 25 \%$.

\subsection{Equilibrium-line altitude reconstruction}

The methods and problems associated with determining equilibrium-line altitudes (ELAs) for high-mountain and sub-tropical glaciers are discussed in Benn and Lehmkuhl (2000), Benn et al. (2005) and Owen and Benn (2005). On the southern side of Mount Everest, last-glacial age lateral moraines are very well preserved, allowing Richards et al. (2000b) to determine the associated ELAs using the maximum elevation of lateral moraines (MELM) method. This method assumes that ice-marginal deposition only occurs below the ELA, and has the advantage that it does not rely on arbitrary assumptions about the mass balance characteristics of the glacier. The MELM method could not be applied in the Rongbuk catchment, however, because of the inaccessibility of the upper part of the glaciers and because the upper lateral moraines could not be clearly seen on 
remote sensing images. Owen and Benn (2005) found that, for the last-glacial Periche glacial stage for the Khumbu and Imja Glaciers, the MELM-derived ELAs implied glacier accumulation area ratios (AAR) of 0.55 , if potential avalanche source areas were included in the glacierized area: we acknowledge that this ratio may have changed over time as precipitation sources may have changed.

In the present study, we reconstructed ELAs for Jilong, Rongbuk and Samdupo I glacial stages of the Rongbuk Glacier using the AAR method, adopting the value of 0.55 obtained for the Periche glacial stage on the southern side of the mountain. Reconstructions of the former glacier tongues were based on end and lateral moraines mapped using a combination of ASTER imagery and observations in the field. In the former accumulation areas, glacier profiles were drawn approximately parallel to the present glacier surfaces. In addition, the catchment of each glacier was delimited by the crests of bounding ridges, based on the observation that snow falling on steep slopes above the glacier accumulation zones contributes to the mass budget. For the Rongbuk and Samdupo glacial stages, the reconstructed glacier outlines were quite similar to those of Mann et al. (1996) (these authors did not attempt a reconstruction of the Jilong glacial stage glacier). In ArcGIS, former ice surfaces were produced by sampling the elevations for the glacier outlines from the SRTM $90 \mathrm{~m}$ DEM and fitting a surface to these points using the Natural Neighbors function (ESRI, 2006). This is equivalent to producing straight line contours across a valley to produce an ice surface. A second surface was produced from the SRTM elevations for the steep 
upper parts of the catchment that contribute through avalanching. These two surfaces were merged for each glacial advance using the Mosaic tool. The AAR of 0.55 was calculated using the Splice function and contours were calculated for the ice surface and the equilibrium line altitude.

\section{Site Descriptions}

The landforms that were sampled for OSL and TCN dating are described below, from oldest to youngest moraine or till $(\mathrm{T})$ where $\mathrm{T} 1$ through $\mathrm{T} 7$ are numbered sequentially.

\subsection{Tingri moraine (T1)}

Scattered m-size erratics are present on valley-side benches at altitudes above $5000 \mathrm{~m}$ asl east of Jilong monastery (Fig. 5A). Highly weathered quartzite and phyllite bedrock is exposed along these benches and covered by a thin (usually $<1 \mathrm{~m}$ thick) diamict or regolith. These characteristics suggest that this moraine has undergone much degradation. The erratics comprise granites and quartzite breccia, which have weathering pits up to several $\mathrm{cm}$ deep. Three samples (Ron-48 to Ron-50) of the quartzite breccias were sampled in preference to the granitic erratics because they were less weathered (Fig. 5A). In addition, three samples of the bedrock were sampled from ridge crests (Fig. 5B).

\subsection{Dzakar moraine (T2)}

The Dzakar moraine comprises multiple ridges on the east side of the Dzakar Chu near the Jilong 
monastery (Fig. 5C). The surfaces are covered with granitic boulders, some of which are $>5 \mathrm{~m}$ in diameter, and are well inset into the moraine surface (Fig. 5D). Samples Ron-37, Ron-38, and Ron-40 to Ron- 45 were collected from boulders on the crest of the largest moraine ridge.

\subsection{Jilong moraine (T3)}

A series of moraine ridges constitute the Jilong moraine $\sim 1 \mathrm{~km} \mathrm{SW}$ of Jilong monastery at $\sim 4960$ $\mathrm{m}$ asl. These can be traced along the eastern side of the Rongbuk valley as a series of discontinuous ridges rising to $>5200 \mathrm{~m}$ asl (Figs. 5E, 5F, 5G). The surfaces of the moraines are covered with $\mathrm{m}$-size boulders some reaching $>5 \mathrm{~m}$ in diameter (Fig. 5F). Samples for TCN dating (Ron-14 to Ron-24) were collected from boulders on the latero-frontal moraine (T3) at its northernmost reach and samples Ron-64 to Ron-67 were collected from a lateral moraine (T3') high ( $\sim 5200 \mathrm{~m}$ asl) on the east side of the Rongbuk valley. The latter moraine was more eroded than the latero-frontal moraine with dm-deep gulleys traversing its surface. Sample OSL-10 for OSL dating was collected from interbedded fine sands and clay sediments excavated in a surface pit on the latero-frontal moraine, while sample OSL-15 was collected from below the till in an exposure of interbedded gravels and fine-medium sands along the road on the east side of the Rongbuk valley (Fig. 3). Samples OSL-4 and OSL-5 were collected from medium-grained sands underlying boulder levee deposits on a tributary paraglacial fan that dissects the Jilong moraine (Fig. 3). 


\subsection{Rongbuk moraine (T4)}

The Rongbuk moraine is located north of the Rongbuk monastery on the east side of the river and road (Fig. 5H) and it comprises at least three ridges that rise $>50 \mathrm{~m}$ above the valley floor. The surface of the moraine comprises m-size granitic boulders (Fig. 5H), while the slopes are armored with boulders to about halfway from the crest to its toe (Fig. 5I). Samples for TCN (Ron-2 to Ron9) dating were collected from the crest of the highest moraine, while samples Ron-10 to Ron-13 were collected from the mid-slope (inflection point) of the moraine (Figs. 5H, 5I). Sample OSL-1 was collected just north of the Rongbuk monastery from stratified gravels and sands within the moraine at a section exposed in an irrigation ditch; a second sample (OSL-2) was collected beneath OSL-1 from a natural exposure of stratified sands underlying the moraine deposits (Fig. 4D). OSL-17 and OSL-22 were collected south of the monastery toward the southern end of the Rongbuk moraine deposit limit in well sorted fine supraglacial sand deposits (OSL-17) and in fluvioglacial medium-grained sand (OSL-22). Rongbuk moraine has experienced modest degradation since deposition, which is manifested in the rounding of the moraine cross profile and the decrease in the frequency of surface boulders toward the flank (Putkonen et al., 2008).

\subsection{Rongbuk Landslide (post T4)}

An extensive area of landslide debris is present $\sim 0.5 \mathrm{~km}$ north of Rongbuk monastery on either side of the Dzakar Chu. This landform was first recognized by Burbank and Kang (1991: Fig. 6). The landslide debris forms a series of arcuate ridges (convex east) that rise several tens of metres 
about the present river level. Metre-size very angular blocks of gneiss and granite are strewn across the surface of the deposit (Figs. 6B, 6C, 6D). Some of these blocks are highly fractured but retain their integrity. At its southern end good exposures are present along the river and yield a complex stratigraphy of stratified diamict containing highly fractured boulders overlaying stratified sand and gravel. Seven samples (Ron-68 to Ron-73) were collected for TCN dating from the large m-size blocks on the surface of the deposit.

\subsection{Samdupo moraines (T5a, T5b and T5c)}

Three distinct sets of sharp crested moraines (T5a, T5b and T5c) comprise the Samdupo moraines that extend between 3 and $5 \mathrm{~km}$ beyond the snout of the contemporary Rongbuk Glacier (Figs. 5J, $5 \mathrm{~K}$ ). These rise several tens of metres above the valley floor that is covered with glaciofluvial outwash sediments. Many of the boulders are perched and are not well inset into the surface of the moraines. A set of TCN samples was collected from the T5b (Ron-34 to Ron-36) and T5c (Ron-25 to Ron-33) moraines, and OSL samples were collected from ablation-valley fill and supraglacial deposits within the equivalent lateral moraines on the valley sides (OSL-6, 12, and 13; Figs. 4B, 4C), from stratified sands and gravels beneath the T5a moraine (OSL-7), and from supraglacial medium-grained sands within the T5c frontal moraine (OSL-9) (Fig. 4A).

\subsection{Xarlungnama moraine (T6)}

The Xarlungnama moraine is the youngest moraine and is clearly separated from the dead ice zone 
of the Rongbuk Glacier (Fig. 5L). This moraine rises several tens of metres above the valley floor and its surface comprises loosely perched angular boulders. TCN samples (Ron-61 to Ron-63) were collected from the crest of this moraine.

\subsection{Supraglacial sediment on the Rongbuk Glacier (T7)}

The lower reaches of the Rongbuk Glacier are debris-covered and transition into a stagnant field of melting ice. Supraglacial sediment and boulder samples (Ron-51 to Ron-58) were collected for TCN dating from the surface of the ice in the lower reaches of the Rongbuk Glacier (Fig. 7).

\subsection{Outwash Terrace}

An impressive outwash terrace is present along the Rongbuk valley beyond the Dzakar moraine. The terrace rises about $>25 \mathrm{~m}$ above the present river level and slopes at about $1.5^{\circ}$ down valley. The surface is armored with m-size highly weathered granitic boulders that are well inset into the surface (Fig. 8). Samples (Ron-74, Ron-75, Ron-77 and Ron-78) were collected for TCN dating from these boulders.

\section{Dating results}

\subsection{OSL dating}

A summary of the dose rate and equivalent dose data $\left(D_{e}\right)$, using the single aliquot regeneration- 
dose (SAR) protocol (Murray and Wintle 2000, 2003; Wintle and Murray, 2006), for the thirteen samples from the three main ice marginal suites of deposits is provided in Table 3, and Figure 9 illustrates the characteristics of the $\mathrm{D}_{\mathrm{e}}$. The $\mathrm{D}_{\mathrm{e}}$ distributions, combined with a comparison of small aliquot and single grain measurements for OSL-1, demonstrate that the samples are fairly well bleached and therefore the quoted $\mathrm{D}_{\mathrm{e}}$ values and ages are based on the mean. Eight OSL ages range from late MIS $3(\sim 26 \mathrm{ka})$ to post-global LGM $(\sim 16 \mathrm{ka})$, the early Holocene $(\sim 7 \mathrm{ka})$, and three samples, one for each moraine, have OSL ages of $\sim 38-40$ ka (Table 3).

\section{2. ${ }^{10}$ Be TCN dating}

Problems associated with the application of TCN methods to dating moraines have been discussed in previous work (e.g. Hallet and Putkonen, 1994; Benn and Owen, 2002; Putkonen and Swanson, 2003; Owen et al., 2002b, 2003a, 2005, 2006a, 2008; Putkonen and O’Neal, 2006; Putkonen at al., 2008; Seong et al., 2007, 2008, 2009). Owen et al. (2008) emphasize two distinct sets of factors that hinder our ability to define glacier chronologies in the Himalaya and elsewhere using TCN surface exposure dating. The first set of factors is geological and includes weathering, exhumation, prior exposure and shielding of the surface by snow and/or sediment. With the exception of prior exposure, these factors generally reduce the concentration of TCNs in rock surfaces and sediments, which results in an underestimate of the true age of the landforms. Episodes of prior exposure result in an overestimate of the true age; but Putkonen and Swanson (2003) showed through the literature analysis of over $600 \mathrm{TCN}$ dated boulders that only about $2 \%$ of all dated boulders had 
prior exposure. The net result of these geological processes can be a large spread in apparent exposure ages on a landform. As Putkonen and Swanson (2003) and Owen et al. (2008) highlighted, these effects might be assessed by collecting multiple samples on a surface that is being dated. The presence of multiple boulders or surface samples having similar apparent ages is taken as evidence that the boulders were not derived from older surfaces and/or were not weathered or exhumed and hence the ages are likely representative of the true age of the surface. In the typical case where a wide range of the boulder ages are obtained for a single landform the most likely explanation is the post-depositional exhumation of fresh boulders to the surface and in the absence of other complications - the oldest of those boulders would reflect the depositional age of the landform.

We acknowledge that the boulders and rock surfaces in this area likely erode at about $2.5 \mathrm{~m} / \mathrm{Ma}$, which as highlighted above, adds a positive correction factor to the age of $<2 \%$ for the Holocene, between $2-5 \%$ for the Late Glacial and global LGM, and $>10 \%$ for ages over $40 \mathrm{ka}$ (cf. Seong et al., 2007, 2009). However, as far as possible we aimed to sample boulders with little evidence of erosion to minimize this effect, and we chose to express our TCN ages without a correction for erosion because we cannot predict the uncertainty with any confidence. Furthermore, we have made no correction for snow cover, since the snow pack in this region is thin today, the area is often swept with strong winds, and we sampled large boulders that generally do not support a thick snow pack. Our TCN ages, however, should likely be considered as minimum estimates of the age 
of the landforms that are being dated in our study.

Hallet and Putkonen (1994) and, more recently, Putkonen et al. (2008) specifically for the Rongbuk moraine suggested that moraine degradation is least in mid-slope position rather than on the moraine crest. To test this hypothesis we sampled several boulders (Ron-10 to Ron-13) from a mid slope position on the Rongbuk moraine. Although the TCN ages on three of these boulders (outlined by the grey box in Figure 11) were within error of the boulders on the moraine crest, they were among the youngest in the distribution, however we acknowledge that a large sample set would be needed to fully test this relationship. Sample Ron-12 was considerably older $(97.3 \pm 8.8$ ka) than any of the other boulders from this moraine and probably represents a boulder that had inherited TCNs prior to its incorporation into this landform.

The second set of factors that introduce uncertainty in surface exposure dating is calculation of the production rate of TCNs. Production rate is dependent upon the cosmic ray flux, which has varied spatially and temporally in association with variations in the geomagnetic field intensity and atmospheric pressure throughout the Quaternary. Currently there is much debate regarding the appropriate scaling models and geomagnetic corrections for TCN production to calculate TCN ages (e.g. Pigati and Lifton, 2004; Staiger et al., 2007; Owen et al., 2008). As highlighted by Balco et al. (2008) and Owen et al. (2008), the biggest uncertainty in scaling models is for low-latitude and high-altitude locations such as the Himalaya. Using the scheme presented in Owen et al. 
(2008), Figure 10 highlights the uncertainty associated with using four different time dependent scaling models and geomagnetic corrections for Mount Everest (calculated using the CRONUS Earth 2 calculator of Balco et al., 2008; http://hess.ess.washington.edu/math/). Figure 10A shows that there is up to $37 \%$ difference in apparent ages among scaling models over the last $50 \mathrm{ka}$ for an altitude of $5000 \mathrm{~m}$ asl. Figure 10B shows that there is also a large variance in ages among scaling models for different altitudes. Differences in ages between scaling models can be as much as $20 \%$, but the difference is $<15 \%$ at altitudes where samples were collected in the Rongbuk valley ( $4800-5250 \mathrm{~m}$ asl). The biggest differences for latitude, longitude and altitude are between the time constant model of Lal (1991) and Stone (2000) and the other models. These uncertainties need to be considered when evaluating the TCN ages presented in our study, and we emphasize that the true uncertainly in the TCN ages may be as much as $20 \%$. However, the geological uncertainty often exceeds $20 \%$. This is particularly apparent for the ages on the Dzakar and Jilong moraines (Fig. 11).

Given the very close proximity between the Rongbuk valley and the Khumbu Himal, production rates scaling problems do not constitute a problem if we use the same age modeling scheme for both regions. The TCN ages for the Rongbuk valley and Khumbu Himal (presented in Figures 11 and 12, and Table 5) are therefore calculated using the same scaling model (Lal, 1991 and Stone, 2000), which allows both regions to be directly compared. Furthermore, the application of OSL methods allows the TCN ages to be tested independent of the problems associated with the 
different age models.

With the exception of the Tingri moraine, the TCN ages for the moraines in the Rongbuk valley are plotted in Figure 11. Each morphostratigraphically older moraine has older TCN ages, which provides a first-order level of confidence in the TCN dating. The spread of ages for each landform increases with increasing age, which likely reflects increasing moraine matrix erosion and exhumation of fresh boulders to the surface. To alleviate the effect of possible older outliers on a moraine age and to facilitate a direct comparison across the massif we also express the ages of each moraine using the mean of the full age distribution with $1 \sigma$ uncertainty. No ages have been excluded from the analysis. However, we separate out the denuded lateral moraine T3' (samples Ron-64 through Ron-67, light blue in Fig. 13A) from inclusion in the age determination for the Jilong moraines, since the erosion and likely exhumation of boulders probably underestimates its true age. Table 2 lists the mean TCN ages for each moraine and the TCN age distribution for each moraine are plotted as probability distributions in Figure 13 to allow an assessment of the relative strength of the data and for a comparison with the TCN ages for the Khumbu Himal. The probability distribution plots are colored similarly between regions for glacial stages that are equivalent in age (within $1 \sigma$ of each other).

The ages for the rock avalanche and outwash terrace provide confidence in the ages for our moraine chronology. The rock avalanche ages cluster at $8.5 \pm 0.2 \mathrm{ka}$, and clearly show that no 
glacier extended down valley below this position after $\sim 8$ ka. Furthermore, given the morphostratigraphic relationships, the rock avalanche postdates the Rongbuk moraine and predates the Samdupo moraines. The outwash terrace shows that no glacier advanced beyond Jilong monastery after 10-15 ka.

\section{Discussion}

Six major glacier advances are defined. The TCN and OSL ages are remarkably similar given the range of uncertainties discussed in the previous sections. This provides confidence in the age estimates for the landforms we dated. The moraines date to $>330 \mathrm{ka}$ (Tingri moraine), $>41 \mathrm{ka}$ (Dzakar moraine), 24-27 ka (Jilong moraine), 14-17 ka (Rongbuk moraine), $\sim 8$ to $2 \mathrm{ka}$ (Samdupo moraines) and $\sim 1.6 \mathrm{ka}$ (Xarlungnama moraine). Given the geomorphic distinctness of each set of moraines and the significant time difference between their timing of formation we attribute each of the moraines to a distinct glacial stage, which we name after the dated moraine. However, the Samdupo stage comprises three distinct moraines, T5a, T5b and T5c. The ages of T5b ( 2.4 ka) and T5c $(\sim 1.5 \mathrm{ka})$ are similar and probably represent the same glacial advance, while T5c is significantly older $(6.8-7.7 \mathrm{ka})$. The Samdupo glacial stage is therefore divided into Samdupo I (older; 6.8-7.7 ka) and Samdupo II (younger; $~ 2.4 \mathrm{ka}$ ). The younger ages on T5b as compared to the morphostratigraphically younger T5c might be the result of toppling of boulders for several hundred years after the glacier retreated since hummocky moraines settle when buried ice melts out. In contrast, the very similar OSL $(2.3 \pm 0.1 \mathrm{ka})$ and TCN $(2.4 \pm 0.2 \mathrm{ka})$ ages on the latero-frontal 
moraine $\mathrm{T} 5 \mathrm{c}$, which is more likely to be stable, suggests that this glacial advance should be defined at 2.3-2.4 ka.

Our task to evaluate the advantage of using the mid-slope boulders instead or in addition to the crestal boulders in moraine dating as suggested by Hallet and Putkonen (1994) and Putkonen and Swanson (2003) resulted in somewhat ambiguous results as the two oldest boulders on the Rongbuk moraine crest (Ron7, and 8) dated substantially older (21.4, and $24.6 \mathrm{ka})$ than the rest of the boulders at the crest (average $14.3 \mathrm{ka}$ ) or at the inflection point at mid-slope (average $12.5 \mathrm{ka}$ ). The oldest boulder of them all (Ron12) at $97.3 \mathrm{ka}$ is probably an outlier and is discarded from further discussion and suggests that despite our view that inheritance is not a problem in this environment a small percentage of boulder could be inherited form older deposits.

Without any additional information it would be tempting to declare the mid-slope sampling at Rongbuk moraine a failure. However, the OSL dates from the same moraine give an age of 15.3 $\mathrm{ka}$, support the view that the landform depositional age is close to $15 \mathrm{ka}$. This is within the error limits of the older mid-slope TCN ages (Ron10) and the largest cluster of TCN boulder ages from the crest. Therefore we suggest that for the Rongbuk moraine, which turned out to be relatively young and only moderately eroded, the mid-slope sampling did not provide significantly different information than the sampling undertaken on the crest of the moraine. However, to fully test Hallet and Putkonen (1994) and Putkonen and Swanson (2003) hypothesis more sampling is required. 
The glacial stages for the Rongbuk valley provide a framework for defining and characterizing the glaciation of the north side of Mount Everest. They compare well with the glacial stages of Finkel et al. (2003) for south side of Mount Everest (Fig. 13; Table 5). There are no glacial landforms in the Khumbu Himal, however, that correlate with the Tingri glacial stage. This is possibly because they have not been preserved on the southern side of Mount Everest. Owen et al. (2005) noted that older glacial landforms were better preserved in the semi-arid interior of Tibet where erosion is less dominant than in the humid south slope of the Himalaya. Therefore, the higher aridity in the Rongbuk valley as compared to the Khumbu Himal might help preserve older landforms. The Tingri glacial stage is likely much older than the TCN ages of $330 \mathrm{ka}$ because of the effects of erosion. This suggests that the Tingri glacial stage occurred during MIS 8 or earlier. Glacial stages of similar antiquity have been recognized in Ladakh, the Central Karakoram, and Pamir (Owen et al., 2006a; Seong et al., 2007, 2009).

The Dzakar glacial stage in the Rongbuk valley correlates well with the Thyangboche II glacial stage in the Khumbu Himal. However, the moraines of the Dzakar glacial stage are better preserved and delimit the former extent of glaciation better than the Thyangboche II moraines. This supports the view that preservation of older moraines is best on the northern slopes of Mount Everest. This glacial advance occurred during MIS 3 and supports the views of Owen et al. (2002a, 2003a, 2005) and Finkel et al. (2003) that the existence of glacial advances during times of 
increased insolation, as outlined in Prell and Kutzbach (1987), is due to increased amounts of moisture delivered by an active south Asian summer monsoon. OSL samples were collected from interbedded fluvioglacial sands and gravels underlying each of the Jilong, Rongbuk and Samdupo moraine deposits (OSL-15, OSL-2 and OSL-7, respectively); the ages of these three samples range from 38-41 ka with the oldest deposit occurring under the Samdupo moraine. The similarity in their ages suggests that there may have been a blanket of alluvium deposited from the present Samdupo limit to beyond the Jilong moraine limit at that time. The OSL depositional ages are older than the TCN ages for the Dzakar moraine and could reflect a rapid ice advance $(\sim 15 \mathrm{~km}$ in $<6 \mathrm{ka}$ ) for the Dzakar glaciation.

There is no evidence for a glacial advance equivalent to the Thyangboche I glacial stage on the north side of Mount Everest. It is tempting to correlate the Thyangboche I glacial stage with the Tingri glacial stage and suggest that the TCN ages for the Thyangboche I moraine are underestimates, however, the considerable difference in ages makes this highly unlikely.

Within the levels of uncertainty associated with TCN and OSL dating (in this case 5-15\%), correlating glacial records throughout Tibet and the Himalayas is possible, particularly for preglobal LGM landforms and sediments driven by Milankovitch forcing. We can confidently make broad statements regarding the maximum extent of glaciation during glacial cycles. 
The Jilong glacial stage in the Rongbuk valley correlates well with the Periche I glacial stage in the Khumbu Himal. These glacial stages likely correlate with the global LGM. Glacial advances during the global LGM in the Himalaya and Tibet are not well defined, but have been dated in the Hunza valley, Nanga Parbat, western Nyainqentanggulha, La Ji, Qilian Shan, Litang, Anyemaqen, Nianboyeze, Sulamu, Kanchenjunga Himal, Gorkha Himal and the Kunlun (Röthlisberger and Geyh, 1985; Owen et al., 2002a, 2003a, b,c, 2005, 2006b; Phillips et al. 2000; Richards et al., 2000a, Schäfer et al., 2002; Meriaux et al., 2004 , Zech et al., 2003; Tsukamoto et al., 2002). These advances were less extensive than glacial advances during the earlier part of the last glacial cycle which supports the interpretation of Gillespie and Molnar (1995) and Benn and Owen (1998) who pointed out that glaciation in mountains was not necessarily in phase with the northern hemisphere ice sheets.

Similarly, the Rongbuk and Periche II glacial stages in the Rongbuk valley and Khumbu Himal, respectively, correlate well to each other at $15-17 \mathrm{ka}$, just after the global LGM, and are possibly coincident with Heinrich I event. Glacial advances at this time are also recognized in other areas of the Himalaya, including the Lahul, Hunza valley, Pamir and the Central Karakoram (Owen et al. 2001, 2002a; Seong et al., 2007, 2009).

An early Holocene glacial advance, at $\sim 10 \mathrm{ka}$, is recognized through much of the monsooninfluenced Himalaya and Tibet, including the Khumbu Himal (Owen et al., 2002a, 2003a,b,c, 2005; 
Finkel et al., 2005). Owen et al. (2002, 2005) and Finkel et al. (2003) emphasized that an early Holocene glacial advance in the monsoon-influence regions of the Himalaya and Tibet reflects increased monsoon precipitation during the early Holocene insolation maximum. Richards et al. (2000a) obtained an OSL age of $10.9 \pm 2.4 \mathrm{ka}$ from near the base of the present-day terminal moraine complex of the Khumbu Glacier. The Samdupo I moraines date to $\sim 7 \mathrm{ka}$, which is considered to be a minimum age. However, given that similar age values have been calculated from three different Samdupo deposits, we believe this advance is significantly younger than a $\sim 10$ ka advance. It is possible that older, potentially early Holocene, Samdupo I deposits have not been sampled. Alternatively, it is also possible that either the early Holocene advance is not preserved or that there was no early Holocene advance in the Rongbuk valley. Given the good degree of preservation in the Rongbuk valley and the age constraints so far, we think that there was no early Holocene Rongbuk glaciation which suggests that the northern slopes were too distal from the monsoon influence during the early Holocene to allow glaciers to grow. Rupper (2007), however, suggests on the basis of climate and ELA modeling that precipitation was not the most important control on determining positive glacier mass balances, but rather that increased cloud cover during summers reduced ablation. Nevertheless, the apparent absence of an early Holocene moraine in the Rongbuk valley needs to be tested by examining adjacent valleys for evidence of early Holocene moraines. 
A significant Neoglacial advance is recognized in the Rongbuk valley (Samdupo II and Xarlungnama glacial stages) and Khumbu Himal (Thukha and Lobuche glacial stages). The numerical dating suggests that the Samdupo II and Thukha glacial stages are asynchronous, and are separated by at least $1 \mathrm{ka}$. If this does not reflect the lack of preservation of landforms or other geological uncertainties in dating, then the asynchroneity may reflect a significant lag time between the response of glaciers to climate change across Mount Everest. The later Xarlungnama and Lobuche glacial stages, however, are broadly synchronous and do not necessarily reflect any lag time in glaciation across Mount Everest. Several studies have suggested that hypsometry can strongly influence the extent of glaciation, resulting in what may appear to be asynchronous glaciations within a mountain range (Furbish and Andrews, 1984; Kerr, 1993; Seong et al., 2009).

Historical, and possibly Little Ice Age, moraines are present around the snout of the Rongbuk glacier. These were not dated and they require further study. However, similar moraines have been dated in the Khumbu Himal to about $\sim 500$ years BP using radiocarbon and TCN methods and likely represent Little Ice Age advances (Benedict, 1976; Fushimi, 1978; Muller, 1980; Finkel, 2003).

Our reconstructed ELAs for the former glacial stages are $6050 \mathrm{~m}$ asl for the Jilong glacial stage, $6100 \mathrm{~m}$ for the Rongbuk glacial stage, and $6140 \mathrm{~m}$ asl for Samdupo glacial stage I. The difference of only $90 \mathrm{~m}$ between the Jilong and Samdupo glacial stages ELAs, despite a $\sim 13 \mathrm{~km}$ difference in 
glacier lengths, reflects the low gradient of the lower Rongbuk valley and the extreme altitudinal range of the upper catchments.

Comparison of the palaeo-ELAs with modern values is complicated by uncertainty over the most appropriate modern ELAs. The glaciers of Mount Everest currently have negative mass balances in response to recent warming (Bolch et al., 2008; Salerno et al., 2008), so the idea of a modern steady state ELA is rather meaningless. Mann et al. (1996) made estimates of glacier ELAs on the north side of Mount Everest based on the highest elevation of rock debris on glacier surfaces, as seen on aerial photographs taken in December 1984. Autumn and early winter are usually times of little precipitation in the Everest region (Bollasina et al., 2002), although in some years cyclones originating in the Bay of Bengal can deliver significant snowfalls in October or November. In a 'normal year' (which 1984 appears to have been), December is probably the optimum time for determining glacier ELAs, because heavy snowfall commonly occurs later in the winter in association with westerly travelling depressions. Although snow cover minima in the Everest region are also likely to occur in May (prior to monsoon onset), observations made at this time are probably less reliable than in the late post-monsoon period due to incomplete melting of spring snow. Mann et al. (1996) estimated 'modern' ELAs of 5760-5840 m asl and 6160-6240 m asl for the Rongbuk and East Rongbuk Glaciers, respectively. The former values are almost certainly too low, because the accumulation area of the Rongbuk Glacier includes extensive snowfields, and it is probable that rock debris only begins to emerge on the glacier surface well below the ELA. This 
conclusion is supported by the maximum elevation of rock debris on numerous other glaciers in the region, which lies in the range 5960-6320 m asl. For the purposes of this study, we adopt a nominal ‘modern' ELA of $6200 \mathrm{~m}$ for the Rongbuk Glaciers.

The above estimates of modern and paleo-ELAs imply an ELA lowering at the Jilong glacial stage (equivalent to the global LGM) relative to the present of $\sim 150 \mathrm{~m}$. This is considerably less than the equivalent ELA lowering in the mid latitudes and tropics (e.g. Porter, 2001; Kaufman et al., 2004; Ivy-Ochs et al., 2008), and implies that the effects of lower air temperature at the global LGM were probably largely offset by reduced precipitation relative to the present, 'starving' the glaciers of moisture. This conclusion is consistent with evidence for restricted LGM glaciers on the south side of Mount Everest (Richards et al., 2000a; Finkel et al., 2003), and ocean-core evidence for a weakened south Asian monsoon at that time (Schulz et al., 2002; Saher et al., 2007).

Our dating results allow direct comparison of reconstructed ELAs on both sides of Mount Everest. The Jilong $(24.3 \pm 3.8 \mathrm{ka})$ and Rongbuk $(16.6 \pm 4.1 \mathrm{ka})$ glacial stages correlate with Periche I $(23.9 \pm 2.5 \mathrm{ka})$ and Periche II $(17.0 \pm 1.7 \mathrm{ka})$ glacial stages, respectively. There are no moraine ages on the southern side that directly correlate with the Samdupo moraines on the north. However, Richards et al. (2000a) obtained an OSL date of $10.9 \pm 2.4$ ka from near the base of the present-day terminal moraine complex of the Khumbu Glacier. The great thickness of sediment above the sample site $(\sim 180 \mathrm{~m})$ implies that the glacier continued to supply debris to the moraine for a 
substantial part of the Holocene. Multiple-crested lateral moraines above the present glacier surface indicate that the debris-covered Khumbu Glacier responded to Holocene climatic fluctuations by thickening and thinning, rather than advance and retreat (cf. Benn and Owen, 2002; Benn et al., 2003), and we conclude that the limits of the Khumbu Glacier have remained essentially unchanged for the last 10,000 years. These limits, therefore, were used to determine a 'Mid-Holocene' ELA for the glacier, assumed equivalent to the Samdupo I glacial stage in the north. We can state with confidence that at $\sim 7$ ka the Khumbu Glacier was no larger than the reconstructed limits.

During the mid-Holocene, ELAs on both sides of Mount Everest were lowered by similar amounts relative to the 'modern' values (Table 6). In contrast, at the global LGM (Jilong and Periche I glacial stages) and during the Late Glacial (Rongbuk and Periche II glacial stages), the amount of ELA lowering was substantially greater on the south side than the north. This implies steeper precipitation gradients across Mount Everest during MIS 2 than in the Holocene, probably reflecting reduced northward penetration of monsoonal weather systems at that time (cf. Inoue, 1977; Müller, 1980; Asahi, 2009). The asymmetric patterns of glacier retreat on either side of Mount Everest possibly reflect shifting climatic gradients across the range. Between $\sim 24$ and $\sim 17$ $\mathrm{ka}$, the Rongbuk Glacier retreated $6 \mathrm{~km}$ in response to an ELA rise of $\sim 50 \mathrm{~m}$. In the same time period, the Khumbu Glacier retreated only $\sim 1 \mathrm{~km}$, with a reconstructed ELA rise of $10 \mathrm{~m}$. This suggests greater glacier sensitivity to climate change on the north side, possibly due to progressive 
precipitation starvation. Between $\sim 17 \mathrm{ka}$ and $\sim 7 \mathrm{ka}$, the ELA of the Rongbuk Glacier rose by a net amount of $40 \mathrm{~m}$; whereas the Khumbu Glacier ELA rose by a net $230 \mathrm{~m}$ (the amount of ice-front retreat was similar in both cases, reflecting the much steeper valley gradient on the south side). The large difference in ELA rise on the northern and southern slopes of the Everest region reflects contrasting responses to increases in both temperature and precipitation in space and time. The lower lying glaciers on the south side would have been more susceptible to Holocene warming, whereas this could have been partially mitigated on the north side by greater penetration of monsoon weather systems across the divide.

\section{Conclusions}

Six major sets of moraines represent significant glacier advances in the Rongbuk valley. These date to $>330 \mathrm{ka}$ (Tingri moraine), $>41 \mathrm{ka}$ (Dzakar moraine), 24-27 ka (Jilong Moraine), 14-17 ka (Rongbuk moraine), 8 to $2 \mathrm{ka}$ (Samdupo moraines) and $1.6 \mathrm{ka}$ (Xarlungnama moraine) and each is assigned to a distinct glacial stage, named after the moraine. This glacial record is very similar to that on the southern slopes of Mount Everest in the Khumbu Himal. These data show that glaciation across the Everest massif was broadly synchronous. However, no early Holocene glacier advance is recognized in the Rongbuk valley, which contrasts with the Khumbu Himal that has a significant advance at this time. This difference suggests that the Khumbu Himal may have been receiving increased monsoon precipitation in the early Holocene that helped increase positive glacier mass balances, while the Rongbuk valley was too sheltered to receive sufficient monsoon 
moisture to allow glaciers to advance. Asymmetric patterns of equilibrium-line altitude rise since the LGM (Table 6) likely reflects changing climatic gradients across the Everest range. This suggests that glaciers are more sensitive to climate change on the northern slopes of Mount Everest, particularly to changes in precipitation associated with monsoon dynamics.

\section{Acknowledgements}

We are grateful to National Geographic Society for funding the field research and part of the dating analysis. Part of this work was undertaken at the Lawrence Livermore National Laboratory (under DOE Contract W-7405-ENG-48). Chaolu Yi and Dewen Li were supported in part by NSFC grants (40730101 and 40671023). Donald Herd and Catriona Barnwell are acknowledged for their technical assistance in the luminescence laboratory at St Andrews. Geoff Duller generously allowed Robinson to conduct single grain analyses on two of the samples in the Aberystwyth Laboratory and his input to those experiments is gratefully acknowledged. Thanks to Will Jeffries for assistance in the field. We thank Chris Clark for discussions and ideas about ELA calculation in ArcGIS. This publication is a contribution from the Scottish Alliance for Geoscience, Environment and Society (SAGES). We thank Neil Glasser and two anonymous reviewers for their careful and constructive reviews of our paper.

\section{References}


Asahi, K. 2009. Equilibrium-line altitudes of the present and Last Glacial Maximum in the eastern Nepal Himalayas and their implications for SW monsoon climate. Quaternary International, In Press, Available online.

Balco, G., Stone, J.O., Lifton, N.A., Dunai T.J., 2008. A complete and easily accessible means of calculating surface exposure ages or erosion rates from 10Be and 26Al measurements. Quaternary Geochronology 8, 174-195.

Barnard, P.L., Owen, L.A., Finkel, R.C., 2006. Quaternary fans and terraces in the Khumbu Himal south of Mount Everest: their characteristics, age and formation. Journal of Geological Society of London 163, 383-399.

Benedict, J.B., 1976. Khumbu glacier series, Nepal. Radiocarbon 18, 177-178.

Benn, D.I., Owen, L.A., 2002. Himalayan glacial sedimentary environments: a framework for reconstructing and dating former glacial extents in high mountain regions. Quaternary International 97/98, 3-26.

Benn, D.I., Lehmkuhl, F., 2000. Mass balance and equilibrium-line altitudes of glaciers in high mountain environments. Quaternary International 65/66, 15-29.

Benn, D.I., Owen L.A., 1998. The role of the Indian summer monsoon and the mid-latitude westerlies in Himalayan glaciation: review and speculative discussion. Journal of the Geological Society $155,353-363$.

Benn, D.I., Kirkbride, M.P., Owen, L.A. and Brazier, V. 2003. Glaciated valley landsystems. In: Evans, D.J.A. (ed.) Glacial Landsystems. London, Arnold, 372-406. 
Benn, D.I., Owen, L.A., Osmaston, H.A., Seltzer, G.O., Porter, C.S., Mark, B., 2005. Reconstruction of equilibrium-line altitudes for tropical and sub-tropical glaciers. Quaternary International 138/139, 8-21.

Bolch, T., Buchroithner, M. F., Pieczonka, T., Kunert, A. 2008. Planimetric and Volumetric Glacier Changes in the Khumbu Himalaya since 1962 Using Corona, Landsat TM and ASTER Data. Journal of Glaciology.

Bollasina, M., L. Bertolani, and G. Tartari, 2002: Meteorological observations in the Khumbu Valley, Nepal Himalayas, 1994-1999, Bulletin of Glacier Research, 19, 1-11.

Briner, J.P., Kaufman, D.S., Manley, W.F., Finkel, R.C., Caffee, M.W., 2005. Cosmogenic exposure dating of late Pleistocene moraine stabilization in Alaska. Geological Society of America Bulletin 117, 1108-1120.

Burbank, D.W., Kang, J.C., 1991. Relative dating of Quaternary moraines, Rongbuk Valley, Mount Everest, Tibet: Implications for an Ice Sheet on the Tibetan Plateau. Quaternary Research 36, 1-18.

Burchfield, B.C., Chen, Z., Hodges, K.V., Liu, Y., Royden, L.H., Deng, C., Xu, J. 1992. The South Tibetan detachment system, Himalyan orogeny: extension contemporaneous with and parallel to shortening in a collisional mountain belt. Geological Society of America Special Paper 269, 1-41.

Dortch, J., Owen, L.A., Haneberg, W.C., Caffee, M.W., Dietsch, C., Kamp, U., 2009. Nature and timing of mega-landslides in northern India. Quaternary Science Reviews, in press.

ESRI, 2006. ArcGIS 9. 380 New York Street, RedLands, CA, USA. 
Finkel, R.C., Owen, L.A., Barnard, P.L., Caffee, M.W., 2003. Beryllium-10 dating of Mount Everest moraines indicates a strong monsoonal influence and glacial synchroniety throughout the Himalya. Geology 31, 561-564.

Fuchs, M., Owen, L.A., 2008. Luminescence dating of glacial and associated sediments: review, recommendations and future directions. Boreas 37, 636-659.

Furbish, D.J., Andrews, J.T., 1984. The use of hypsometry to indicate long-term stability and response of valley glaciers to changes in mass transfer. Journal of Glaciology 105, 199-211.

Fushimi, H., 1977. Glaciations in the Khumbu Himal. Seppyo 39, 60-67.

Fushimi, H., 1978. Glaciations in the Khumbu Himal. Seppyo 40, 71-77.

Gillespie, A., Molnar, P., 1995. Asynchronous maximum advances of mountain and continental glaciers. Reviews of Geophysics 33, 311-364.

Hallet, B., Putkonen, J., 1994. Surface dating of dynamic landforms: young boulders on aging moraines. Science 265, 937-940.

Huang, M., 1990. On the temperature distribution of glaciers in China. Journal of Glaciology 36, 210-216.

Inoue, J., 1977. Mass budget of Khumbu Glacier. Seppyo 39, 15-19.

Ivy-Ochs, S., Kerschner, H., Reuther, A., Preusser, F., Heine, K., Maisch, M., Kubik, P.W. and Schlüchter, C. 2008. Chronology of the last glacial cycle in the European Alps. Journal of 
Quaternary Science 23, 559-573.

Iwata, S., 1976. Late Pleistocene and Holocene moraines in the Sagarmatha (Everest) region, Khumbu Himal. Seppyo 38, 109-114.

Kaufman, D.S., Porter, S.C. and Gillespie, A.R. 2004. Quaternary alipne glaciation in Alaska, the Pacific Northwest, Sierra Nevada, and Hawaii. In: Gillespie, A.R., Porter, S.C. and Atwater, B.F. (eds.) The Quaternary Period in the United States. Amsterdam, Elsevier, 77-104.

Kerr, A., 1993, Topography, climate and ice masses: A review. Terra Nova 5, 332-342.

Kuhle, M., 1985. Ein subtropisches Inlandeis als Eiszeitauslöser, Südtibet un Mt. Everest expedition 1984. Geogia Augusta, Nachrichten aus der Universität Gottingen, May, 1-17.

Kuhle, M., 1988. Geomorphological findings on the built-up of Pleistocene glaciation in Southern Tibet and on the problem of inland ice. GeoJournal 17, 457-512.

Kuhle, M., 2005. Glacial geomorphology and ice ages in Tibet and the surrounding mountains. The Island Arc 14, 346-367.

Kuhle, M., 2007. The past valley glacier network in the Himalayas and the Tibetan ice sheet during the last glacial period and its glacial-isostatic,eustatic and climatic consequences. Tectonophysics 445, 116-144.

Lal, D., 1991. Cosmic ray labeling of erosion surfaces: in situ nuclide production rates and erosion models. Earth and Planetary Science Letters 104, 429-439. 
Law, R.D., Searle, M.P., Simpson, R.L., 2004. Strain, deformation temperatures and vorticity of flow at the top of the Greater Himalayan Slab, Everest Massif, Tibet. Journal of the Geological Society $161,305-320$.

Lehmkuhl F, Owen LA. 2005. Late Quaternary glaciation of Tibet and the bordering mountains: a review. Boreas 34: 87-100.

Mann, D.H, Sletten, R.S, Reanier, R.E. 1996. Quaternary glaciation of the Rongbuk Valley, Tibet. Journal of Quaternary Science 11, 267-280.

Meriaux, A.-S., Ryerson, F.J., Tapponnier, P., Van der Woerd, J., Finkel, R.C., Xu, X., Xu, Z., Caffee, M.W., 2004. Rapid slip along the central Altyn Tagh Fault: morphochronologic evidence from Cherchen He and Sulamu Tagh. Journal of Geophysical Research 109, B06401.

Mix, A.C., Bard, E., Schneider, R., 2001. Environmental processes of the ice age: land, ocean, glaciers (EPILOG). Quaternary Science Reviews 20, 627-657.

Müller, F., 1980. Present and late Pleistocene equilibrium line altitudes in the Mt. Everest regionAn application of the glacier inventory. World Glacier Inventory 126, 75-94.

Murray, A.S., Olley, J.M., 2002. Precision and accuracy in the optically stimulated luminescence dating of sedimentary quartz: a status review, Geochronometria 21, 1-16.

Murray, A.S., Wintle, A.G.., 2000. Luminescence dating of quartz using an improved single-aliquot regenerative-dose protocol, Radiation Measurements 32, 57-73.

Murray, A.S., Wintle, A.G., 2003. The single aliquot regenerative dose protocol: potential for 
improvements in reliability, Radiation Measurements 37, 377-381.

Nishiizumi, K., Imamura, M., Caffee M.W., Southon, J. R., Finkel, R. C. McAninch J., 2007. Absolute calibration of Be-10 AMS standards. Nuclear Instruments \& Methods in Physics Research Section B-Beam Interactions with Materials and Atoms 258, 403-413.

Owen, L.A., Benn, D.I. 2005. Equilibrium-line altitudes of the Last Glacial Maximum for the Himalaya and Tibet: an assessment and evaluation of results. Quaternary International 138/139, $55-78$.

Owen LA, Gualtieri L, Finkel RC, Caffee MW, Benn DI, Sharma MC. 2001. Cosmogenic radionuclide dating of glacial landforms in the Lahul Himalaya, northern India: defining the timing of Late Quaternary glaciation. Journal of Quaternary Science 16: 555-563.

Owen LA, Finkel RC, Caffee MW, Gualtieri L. 2002a. Timing of multiple Late Quaternary glaciations in the Hunza Valley, Karakoram Mountains, northern Pakistan: Defined by cosmogenic radionuclide dating of moraines. Geological Society of America Bulletin 114: 593-604.

Owen, L.A., Kamp, U., Spencer, J.Q., Haserodt, K., 2002b. Timing and style of Late Quaternary glaciation in the eastern Hindu Kush, Chitral, northern Pakistan: a review and revision of the glacial chronology based on new optically stimulated luminescence dating. Quaternary International 97/98, 41-55.

Owen, L.A., Finkel, R.C., Ma, H., Spencer, J.Q., Derbyshire, E., Barnard, P.L., Caffee, M.W., 2003a. Timing and style of Late Quaternary glaciations in NE Tibet. Geological Society of America Bulletin 115, 1356-1364. 
Owen LA, Ma H, Derbyshire E, Spencer JQ, Barnard PL, Zeng YN, Finkel RC, Caffee MW. 2003b. The timing and style of Late Quaternary glaciation in the La Ji Mountains, NE Tibet: evidence for restricted glaciation during the latter part of the Last Glacial. Zeitschrift für Geomorphologie 130: 263-276.

Owen LA, Spencer JQ, Ma H, Barnard PL, Derbyshire E, Finkel RC, Caffee MW, Zeng YN. 2003c. Timing of Late Quaternary glaciation along the southwestern slopes of the Qilian Shan, Tibet. Boreas 32: 281-291.

Owen, L.A., Finkel, R.C., Barnard, P.L., Haizhou, M., Asahi, K., Caffee, M.W., Derbyshire, E., 2005. Climatic and topographic controls on the style and timing of Late Quaternary glaciation throughout Tibet and the Himalaya defined by $10 \mathrm{Be}$ cosmogenic radionuclide surface exposure dating. Quaternary Science Reviews 24, 1391-1411.

Owen, L.A., Caffee, M.W., Bovard, K.R., Finkel, R.C., Sharma, M.C., 2006a. Terrestrial cosmogenic nuclide surface exposure dating of the oldest glacial successions in the Himalayan orogen. Ladakh Range, northern India. Geological Society of America Bulletin 118, 383-392.

Owen, L.A., Finkel, R.C., Ma, H., Barnard, P.L., 2006b. Late Quaternary landscape evolution in the Kunlun Mountains and Qaidam Basin, Northern Tibet: a framework for examining the links between glaciation, lake level changes and alluvial fan formation. Quaternary International $154 / 155,73-86$

Owen, L.A., Caffee, M.W., Finkel, R.C., Seong, B.Y., 2008. Quaternary glaciations of the Himalayan-Tibetan orogen. Journal of Quaternary Science 23, 513-532.

Phillips WM, Sloan VF, Shroder JF Jr, Sharma P, Clarke ML, Rendell, HM 2000. Asynchronous 
glaciation at Nanga Parbat, northwestern Himalaya Mountains, Pakistan. Geology 28: 431-434.

Pigati, J.S., Lifton, N.A., 2004. Geomagnetic effects on time-integrated cosmogenic nuclide production with emphasis on in situ ${ }^{14} \mathrm{C}$ and ${ }^{10} \mathrm{Be}$. Earth and Planetary Science Letters 226, 193205.

de Pison, E.M., Lopez, J., Nicolas, P., 1986. Observaciones geomorfologicas en la vertiente Tibetana del Everest: Expedicion Espanola al Qomolangma. Universidad Autonoma de Madrid, Madrid-Espana, $159 \mathrm{p}$

Porter, S.C. 2001. Snowline depression in the tropics during the Last Glaciation. Quaternary Science Reviews 20, 1067-1091.

Prell, W.L., Kutzbach, J.F., 1987. Monsoon variability over the past 150,000 yr. Journal of Geophysical Research 92, 8411-8425.

Prescott, J.R., Hutton, J.T., 1994. Cosmic ray contributions to dose rates for luminescence and ESR dating: Large depths and long-term time variations. Radiation Measurements 23, 497-500.

Putkonen, J., Swanson, T., 2003. Accuracy of cosmogenic ages for moraines. Quaternary Research $59,255-261$.

Putkonen, J., O'Neal, M.A., 2006. Degradation of unconsolidated Quaternary landforms in the western North America. Geomorphology 75, 408-419.

Putkonen, J., Connolly, J., Orloff, T., 2008. Landscape evolution degrades the geologic signature of past glaciations. Geomorphology 97, 208-217, doi:10.1016/j.geomorph.2007.02.043. 
Richards, B.W.M., 2000. Luminescence dating of Quaternary sediments in the Himalaya and High Asia: a practical guide to its use and limitations for constraining the timing of glaciation. Quaternary International 65/66: 49-61.

Richards, B.W.M., Owen, L.A., Rhodes, E.J., 2000a. Timing of Late Quaternary glaciations in the Himalayas of northern Pakistan. Journal of Quaternary Science 15: 283-297.

Richards, B.W.M., Benn, D.I., Owen, L.A., Rhodes, E.J., Spencer, J.Q., 2000b. Timing of Late Quaternary glaciations south of Mount Everest in the Khumbu Himal, Nepal. Geological Society of America Bulletin 112, 1621-1632.

Robinson, R.A.J., Spencer, J.Q.G., Strecker, M.R., Richter, A., Alonso R.N., 2005. Luminescence dating of alluvial fans in intramontane basins of NW Argentina. In: Alluvial Fans: Geomorphology, Sedimentology, Dynamics. Geological Society, London, Special Publications 251, 154-168.

Röthlisberger F., Geyh M. 1985. Glacier Variations in Himalayas and Karakoram. Zeitschrift für Gletscherkunde und Glazialgeologie 21: 237-249.

Saher, M.H., Peeters, F.J.C. and Kroon, D. 2007. Sea surface temperatures during the SW and NE monsoon seasons in the western Arabian Sea over the past 20,000 years. Palaeogeography, Palaeoclimatology, Palaeoecology 249, 216-228.

Salerno, F., Buraschi, E., Bruccoleri, G., Tartari, G., and Smiraglia, C. 2008. Glacier surface-area changes in Sagarmatha National Park, Nepal, in the second half of the 20th century, by comparison of historical maps. Journal of Glaciology 54 (187), 738-752 
Schulz, H., von Rad, U. and Ittekkot, V. 2002. Planktic formaninifera, particle flux and oceanic productivity off Pakistan, NE Arabian Sea: modern analogues and application to the palaeoclimatic record. In: The Tectonic and Climatic Evolution of the Arabia Sea Region. Geological Society of London, Special Publications vol. 195, 499-516.

Searle, M.P., Simpson, R.L., Law, R.R., Parrish, R.R., Waters, D.J., 2003. The structural geometry, metamorphic and magmatic evolution of the Everest massif, High Himalaya of Nepal-South Tibet. Journal of the Geological Society 160, $345-366$.

Seong, Y.B., Owen, L.A., Bishop, M.P., Bush, A., Clendon, P., Copland, P., Finkel,. R., Kamp, U., Shroder, J.F., 2007. Quaternary Glacial History of the Central Karakoram. Quaternary Science Reviews 26, 3384-3405.

Seong, Y.B., Owen, L.A., Bishop, M.P., Bush, A., Clendon, P., Copland, P., Finkel,. R., Kamp, U., Shroder, J.F., 2008. Reply to comments by Matthias Kuhle on "Quaternary glacial history of the central Karakoram”. Quaternary Science Reviews 27, 1656-1658

Seong, Y.B., Owen, L.A., Finkel, R.C., Yi, C., 2009. Quaternary glaciation of Muztag Ata and Kongur Shan: evidence for glacier response to rapid climate changes throughout the Late-glacial and Holocene in westernmost Tibet. GSA Bulletin, in press.

Schäfer, J.M., Tschudi, S., Zhizhong, Z., Xihao, W., Ivy-Ochs, S., Wieler, R., Baur, H., Kubik, P.W., Schluchter, C., 2002. The limited influence of glaciation in Tibet on global climate over the past 170,000 yr. Earth and Planetary Science Letters 194, 287-297.

Spencer, J.Q., Owen, LA., 2004. Optically stimulated luminescence dating of Late Quaternary glaciogenic sediments in the upper Hunza valley: validating the timing of glaciation and assessing 
dating methods. Quaternary Sciences Reviews 23, 175-191.

Spencer, J.Q.G., Robinson, R.A.J., 2008. Dating intramontane alluvial deposits from NW Argentina using luminescence techniques: Problems and potential, Geomorphology 93, 144-151.

Spencer, J.Q., Sanderson, D.C.W., Deckers, K., Sommerville, A.A., 2003. Assessing mixed dose distributions in young sediments identified using small aliquots and a simple two-step SAR procedure: the F-statistic as a diagnostic tool, Radiation Measurements 37, 425-431.

Staiger, J., Gosse, J., Toracinta, R., Oglesby, B., Fastook, J., Johnson, J.V., 2007. Atmospheric scaling of cosmogenic nuclide production: Climate effect. Journal of Geophysical Research 112: B02205, doi:10.1029/2005JB003811.

Stone, J.O., 2000. Air pressure and cosmogenic isotope production. Journal of Geophysical Research 105, 23753-23759.

Tsukamoto, S., Asahi, K., Watanabe, T., Kondo, R., Rink, W.J., 2002. Timing of past glaciation in Kanchenjunga Himal, Nepal by optically stimulated luminescence dating of tills. Quaternary International 97/98, 57-68.

Wallinga, J., Murray, A.S., Bøtter-Jensen, L., 2002. Measurement of the dose in quartz in the presence of feldspar contamination, Radiation Protection Dosimetry 101, 367-370.

Williams, Van S., 1983. Present and former equilibrium-line altitudes near Mount Everest, Nepal and Tibet. Arctic and Alpine Research 15, 201-211.

Wintle, A.G., Murray, A.S., 2006. A review of quartz optically stimulated luminescence 
characteristics and their relevance in single-aliquot regeneration dating protocols, Radiation Measurements 41, 369-391.

Zech, W., Glaser, B., Abramowski, U., Dittmar, C., Kubik, P.W.. 2003. Reconstruction of the Late Quaternary Glaciation of the Macha Khola valley (Gorkha Himal, Nepal) using relative and absolute (14C, 10Be, dendrochronology) dating techniques. Quaternary Science Reviews 22, 2253-2265.

Zheng, B., 1988. Quaternary glaciation of Mt. Qomolongma-Xixabangma region. GeoJournal 17, $525-542$.

Zheng, B., 1989. Controversy regarding the existence of a large ice sheet on the Qinghai-Xizang (Tibetan) Plateau during the Quaternary Period. Quaternary Research 32, 121-123. 


\section{Figures}

Fig. 1. (A) Low oblique photograph (STS076-727-080) taken in March 1996 looking SW across the Himalaya showing the location of the study area, and (B) low-oblique photograph (STS066208-25) taken November 1994 looking south across the study area at Mount Everest from Tibet to Nepal. Photograph (B) was taken during the morning, and shadows are west of the high features; Mount Everest casts the largest shadow (from Image Science and Analysis Laboratory, NASAJohnson Space Center." The Gateway to Astronaut Photography of Earth", http://earth.jsc.nasa.gov/sseop/EFS/query.pl).

Fig. 2. The main moraines and sampling sites for numerical dating located on an ASTER of the Rongbuk valley.

Fig. 3. Schematic diagram showing the stratigraphic context and locations for samples for OSL dating.

Fig. 4. Views of typical sampling locations for OSL dating. A) Location of OSL samples up the Rongbuk valley showing details of the sampling location for OSL-9 in the Samdupo T5c moraine. B-D) Overview and details of the sampling locations for OSL-12 and OSL-6 in the Samdupo T5a moraine, and OSL-1 and OSL-2 in the Rongbuk moraine.

Fig. 5. Views of glacial landforms in the Rongbuk valley. (A) Scattered erratics at $5100 \mathrm{~m}$ asl comprising the Tingri moraines (T1). The leucrogranite boulder (Ron-49) was sampled for ${ }^{10} \mathrm{Be}$ TCN dating. (B) Glacially eroded bedrock of the Tingri glacial stage (T1) at $\sim 5220 \mathrm{~m}$ asl above Rongpudoi that was sampled (Ron-46) for ${ }^{10} \mathrm{Be}$ TCN dating; (C) View west looking across Dzakar glacial stage moraines (T2). D) Typical boulder (Ron-40) sampled on the Dzakar glacial stage moraine (T2). E) View looking north up the Jilong glacial stage moraines (T3) near Rongpudoi and (F) a typical boulder (Ron-33) that was sampled for ${ }^{10} \mathrm{Be}$ TCN dating. (G) View north at 5200 
$\mathrm{m}$ asl on the east side of the Rongbuk valley from valley slopes above the valley at a remnant of the Jilong glacial stage moraine (Surprise; T3) and a view of a boulder (Ron-65) that was sampled for ${ }^{10} \mathrm{Be}$ TCN dating. (H) View south along the Rongbuk glacial stage moraine (T4) showing a typical boulder that was sampled (Ron-2) for ${ }^{10} \mathrm{Be}$ TCN dating, $\sim 2 \mathrm{~km}$ south of the Rongbuk Glacier. (I) View of mid-slopes of the Rongbuk glacial stage moraines (T4) showing where samples Ron-10 to Ron-13 were sampled for ${ }^{10} \mathrm{Be}$ TCN dating. (J) View south along the crest of a hummocky moraine of the Samdupo glacial stage moraine (T5b) and showing a boulder (Ron-34) sampled for ${ }^{10} \mathrm{Be}$ dating $\sim 1 \mathrm{~km}$ north of the Rongbuk Glacier. (K) View south across a laterofrontal moraine of the Samdupo glacial stage (T5c) showing a boulder (Ron-27) that was sampled for ${ }^{10} \mathrm{Be}$ TCN dating; L) View north across Xarlungnama moraine (T6) $<1 \mathrm{~km}$ north of the Rongbuk Glacier.

Fig. 6. View of landslide deposit at Rongbuk (A) looking west from $\sim 5000 \mathrm{~m}$ asl. Note the convex form and extensive alluvial fan that onlaps the landslide deposit. (B) Typical landslide debris, comprising m-size blocks of angular augen gneiss and leucogranite in a matrix of poorly sorted silt and sand. (C) Augen gneiss block that was sampled twice (Ron-73A and Ron-73B) and (D) a leucogranite boulder that was sampled (Ron-71) for ${ }^{10} \mathrm{Be} \mathrm{TCN}$ surface exposure dating.

Fig. 7. View of across the surface of the Rongbuk Glacier showing typical sampling locations for (A) supraglacial boulders (Ron-55) and (B) supraglacial debris (Ron-55) that was sampled for ${ }^{10} \mathrm{Be}$ TCN dating.

Fig. 8. View of outwash terrace at $4840 \mathrm{~m}$ asl in the lower Rongbuk valley showing a boulder (Ron-74) that was sampled for ${ }^{10} \mathrm{Be} \mathrm{TCN}$ dating.

Fig. 9. OSL data for all samples. (A) Radial plots for equivalent doses arranged in vertical columns according to age and by moraine area. (B) Radial plot of $\mathrm{D}_{\mathrm{e}}$ values resulting from single grain 
SAR analysis for comparison with measurements from single aliquot analysis (first radial plot shown in A). (C) Decay curve for OSL-1 for the natural signal with inset plot showing a growth curve and recycling behaviour for one aliquot. (D) Dose recovery data for six of the samples plotted against pre-heat temperature showing dependence of $D_{e}$ on temperature; Grey box shows acceptance region for dose recovery tests. Final SAR measurements were measured using a preheat of $240-260^{\circ} \mathrm{C}$.

Fig. 10. Percentage exposure age difference over the last 50 ka between time constant scaling method (Lal, 1991; Stone, 2000) and various time-varying scaling schemes for (A) Mount Everest $27.99^{\circ} \mathrm{N} / 86.99^{\circ} \mathrm{E}$ at $5000 \mathrm{~m}$ asl $(80.00$ atom $/ \mathrm{g} / \mathrm{yr}$ (spallation) and 0.823 atoms $/ \mathrm{g} / \mathrm{yr}$ (muons)) and (B) for altitudes ranging from 1000 to $7500 \mathrm{~m}$ asl for Mount Everest.

Fig. 11. ${ }^{10} \mathrm{Be}$ TCN and OSL ages for the landforms dated along the Rongbuk valley plotted by relative age. ${ }^{10} \mathrm{Be}$ ages from the same moraine crest are enclosed by black boxes. The grey boxes are for boulders from mid-slope positions. The ages for the Tingri glacial stage are not plotted on this graph and the ages for the outwash surface in the lower Rongbuk valley is plotted separately to the right of the figure.

Fig. 12. ${ }^{10} \mathrm{Be}$ TCN and OSL ages for the landforms dated in the Khumbu Himal plotted as relative age (after Richards et al., 2000 and Finkel et al., 2003). The ${ }^{10} \mathrm{Be}$ ages have been recalculated using Lal (1991) and Stone (2000) time-independent method.

Fig. 13. Comparison of ${ }^{10} \mathrm{Be}$ TCN ages across Mt. Everest for (A) the Rongbuk valley and (B) for the Khumbu Himal plotted as probability distributions. At the top of each figure, the average and standard deviation is plotted for each glacial stage. The ${ }^{10} \mathrm{Be}$ TCN ages for the Khumbu Himal have been recalculated using Lal (1991) and Stone (2000) time-independent method. 
Fig. 14. Reconstructions of the glacial extent plotted on a digital elevation model (determined from ASTER imagery) for (left to right): the Jilong and Periche I glacial stages; Rongbuk and Periche II glacial stages; and the Samdupo I and Chhukung glacial stages.

Fig. 15. Profile across Everest showing ELA reconstructions for the Jilong, Periche I, Rongbuk, Pheriche II, Samdupo I and Chhukung glacial stages (the profile line is shown in Figure 14).

\section{Tables}

Table 1. Tentative correlations, relative chronologies and numerical dates for the glacial successions in the Khumbu Himal south of Mt. Everest adapted from Finkel et al. (2003) with recalculated ${ }^{10} \mathrm{Be} \mathrm{TCN}$ ages.

Table 2. Comparison of previous glacial chronologies with this study for the Rongbuk Valley on the northern slopes of Mt. Everest.

Table 3. Equivalent dose $\left(D_{e}\right)$ data, dose-rates and OSL ages for 180-212 $\mu \mathrm{m}$ quartz.

Table 4. Data for ${ }^{10} \mathrm{Be}$ TCN surface exposure samples using Lal (1991)/Stone (2000) timeindependent scaling model with $0 \mathrm{~m} / \mathrm{Ma}$ erosion.

Table 5. Correlation of glacial stages across Mount Everest and former ELAs.

Table 6. Former ELAs for selected stages of the Rongbuk and Khumbu Glaciers (based on an AAR of 0.55). 
Table 1

Tentative correlations, relative chronologies and numerical dates for the glacial successions in the Khumbu Himal south of

Mt. Everest adapted from Finkel et al. (2003) with recalculated ${ }^{10} \mathrm{Be}$ TCN ages.

\begin{tabular}{|c|c|c|c|c|c|c|}
\hline Iwata (1976) & $\begin{array}{l}\text { Fushimi (1977) } \\
\text { (1) }\end{array}$ & $\begin{array}{c}\text { Van Williams } \\
\text { (1983) }\end{array}$ & $\begin{array}{l}\text { Muller (1980), Benedict } \\
\text { (1976), Fushimi (1978) }\end{array}$ & $\begin{array}{c}\text { Richards et al. } \\
(2000 \mathrm{a})\end{array}$ & $\begin{array}{c}\text { Finkel et al. } \\
(2003)^{10} \mathrm{Be} \text { ages }\end{array}$ & $\begin{array}{c}\text { Recalculated } \\
{ }^{10} \mathrm{Be} \text { ages }\end{array}$ \\
\hline & & & $\begin{array}{l}\text { Outer moraine (Pumore) } \\
(\sim 410-550 \text { C-14 yrs BP })\end{array}$ & & $\begin{array}{c}\text { Historical } \\
(<500 \text { yrs BP })\end{array}$ & $\begin{array}{c}\text { Historical } \\
(<500 \text { yrs BP })\end{array}$ \\
\hline $\begin{array}{l}\text { Lobuche I-III } \\
\text { (Late } \\
\text { Holocene*) }\end{array}$ & $\begin{array}{l}\text { Thuklha 3-4 } \\
\text { (Late } \\
\text { Holocene*) }\end{array}$ & $\begin{array}{l}\text { Yykugikcga I-III } \\
\text { (Late Holocene*) }\end{array}$ & $\begin{array}{c}\text { Outer moraine } \\
\text { (Tsola) } \\
(\sim 1150-1200 \mathrm{C}-14 \mathrm{yrs} \\
\text { BP })\end{array}$ & $\begin{array}{l}\text { Lobuche } \\
(\sim 1-2 \mathrm{ka}: \\
\text { OSL dating) }\end{array}$ & $\begin{array}{l}\text { Lobuche } \\
(\sim 1 \mathrm{ka})\end{array}$ & $\begin{array}{l}\text { Lobuche } \\
(\sim 1.1 \pm 0.4 \mathrm{ka})\end{array}$ \\
\hline \multirow[t]{2}{*}{$\begin{array}{l}\text { Thuklha } \\
\left(<5 \mathrm{ka}^{*}\right)\end{array}$} & $\begin{array}{l}\text { Thuklha } 1 \\
\left(<5 \mathrm{ka}^{*}\right)\end{array}$ & $\begin{array}{c}\text { Tamba } \\
\left(<5 \mathrm{ka}^{*}\right)\end{array}$ & Dhugla I and II & & $\begin{array}{l}\text { Thuklha } \\
\text { (3.6 } \pm 0.3 \mathrm{ka})\end{array}$ & $\begin{array}{l}\text { Thuklha } \\
(3.5 \pm 0.3 \mathrm{ka})\end{array}$ \\
\hline & & & & $\begin{array}{l}\text { Chhunkung } \\
(\sim 10 \mathrm{ka:} \\
\text { OSL dating) }\end{array}$ & $\begin{array}{l}\text { Chhunkung } \\
(9.2 \pm 0.2)\end{array}$ & $\begin{array}{l}\text { Chhunkung } \\
(10.1 \pm 0.4)\end{array}$ \\
\hline $\begin{array}{l}\text { Periche }^{\dagger} \\
{\text { (ca. } 20 \mathrm{ka}^{*} \text { ) }}\end{array}$ & 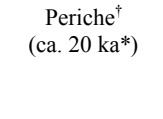 & $\begin{array}{c}\text { Lhaog } \\
\text { (ca. } 20 \mathrm{ka}^{*} \text { ) }\end{array}$ & & $\begin{array}{l}\text { Periche }{ }^{\dagger} \\
\text { (18-25 ka: } \\
\text { OSL dating) }\end{array}$ & $\begin{array}{l}\text { Periche }{ }^{\dagger} I I \\
(16 \pm 2 \text { ka: }) \\
\text { Pheriche }{ }^{\top} \mathrm{I} \\
(23 \pm 3 \mathrm{ka})\end{array}$ & 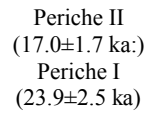 \\
\hline \multirow[t]{2}{*}{$\begin{array}{l}\text { Thyangboche } \\
\text { (ca. 40-50*) }\end{array}$} & & & & & 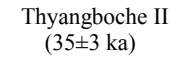 & $\begin{array}{l}\text { Thyangboche II } \\
(40.0 \pm 5.0 \mathrm{ka})\end{array}$ \\
\hline & & & & & 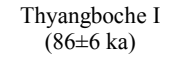 & $\begin{array}{l}\text { Thyangboche I } \\
(68.1 \pm 34.6 \mathrm{ka})\end{array}$ \\
\hline \multirow{2}{*}{$\begin{array}{l}\text { Platform } \\
\left(>150^{*}\right)\end{array}$} & U1 & & & & & \\
\hline & U2-3 & & & & & \\
\hline
\end{tabular}

* The ages quoted are estimations of the age of the moraines based on relative weathering criteria and tentative correlation with glacial succession elsewhere in the world. 


\begin{tabular}{|c|c|c|c|c|c|c|c|c|c|}
\hline \multirow{2}{*}{$\begin{array}{l}\text { Tentative assignments } \\
\text { for previous studies }\end{array}$} & \multicolumn{7}{|c|}{ Moraine/glacial stage name } & \multirow{2}{*}{$\begin{array}{c}\text { TCN ages } \\
(\text { mean \& } \sigma) \\
(\mathrm{ka})\end{array}$} & \multirow{2}{*}{$\begin{array}{c}\text { OSL ages } \\
\text { (ka) }\end{array}$} \\
\hline & Pison et al. (1986) & Kuhle (1988) & Zheng (1989) & $\begin{array}{c}\text { Burbank and Kang } \\
\text { (1991) }\end{array}$ & Mann et al. (1996) & This study & This study & & \\
\hline Little Ice Age & $\begin{array}{c}\text { Little Ice } \\
\text { Age/Historical) } \\
\text { (G1) }\end{array}$ & $\begin{array}{l}\text { X-VIII (Dead } \\
\text { ice) } \\
\text { VI (Dhaulagiri } \\
\text { stage) }\end{array}$ & $\begin{array}{l}\text { Little Ice Age } \\
\text { moraine }\end{array}$ & & $\begin{array}{c}\text { Xarlungnama } \\
\text { moraine }\end{array}$ & T6 & $\begin{array}{c}\text { Xarlungnama } \\
\text { moraine }\end{array}$ & $1.6 \pm 0.1$ & \\
\hline Neoglacial & $\begin{array}{l}\text { Song Duo Po (G2) } \\
\text { Song Duo Po (G3) }\end{array}$ & $\begin{array}{c}\text { VI } \\
\text { (older } \\
\text { Dhaulagiri } \\
\text { stage) }\end{array}$ & $\begin{array}{l}\text { Rongbude } \\
\text { Neoglacial } \\
\text { moraines }\end{array}$ & $\begin{array}{l}\text { Neoglacial } \\
\text { moraine }\end{array}$ & $\begin{array}{c}\text { Samdupo moraine } \\
\left(>540 \pm 500^{14} \mathrm{C} \mathrm{yr}\right. \\
\text { BP; } 1920 \pm 600^{14} \mathrm{C} \\
\text { yr BP })\end{array}$ & $\begin{array}{l}\mathrm{T} 5 \mathrm{c} \\
\mathrm{T} 5 \mathrm{~b}\end{array}$ & $\begin{array}{c}\text { Samdupo c } \\
\text { (latero-frontal } \\
\text { moraine) } \\
\text { Samdupo b } \\
\text { (hummocky } \\
\text { moraine) }\end{array}$ & $\begin{array}{l}2.4 \pm 0.2 \\
1.5 \pm 0.3\end{array}$ & $2.3 \pm 0.1$ \\
\hline Mid-Holocene & & V (Nauri stage) & & & & T5a & Samdupo a & & $\begin{array}{l}6.8 \pm 0.6 \\
6.8 \pm 0.5 \\
7.7 \pm 0.3\end{array}$ \\
\hline $\begin{array}{l}\text { Early Holocene } \\
\text { Late Glacial }\end{array}$ & Rongbuk (G4) & $\begin{array}{l}\text { IV (Sirkung } \\
\text { stage) } \\
\text { III (Dhampu } \\
\text { stage) } \\
\text { II (Taglung } \\
\text { stage) }\end{array}$ & $\begin{array}{l}\text { Rongbu } \\
\text { moraine }\end{array}$ & & $\begin{array}{c}\text { Rongbuk and } \\
\text { Rongpudoi } \\
\text { moraines } \\
\left(>9520 \pm 600^{14} \mathrm{C} \text { yr }\right. \\
\text { BP })\end{array}$ & $\mathrm{T} 4$ & $\begin{array}{l}\text { Rongbuk } \\
\text { moraines }\end{array}$ & $16.6 \pm 4.1$ & $\begin{array}{l}14.2 \pm 0.9 \\
15.5 \pm 0.6 \\
16.3 \pm 0.8\end{array}$ \\
\hline LGM (MIS 2) & $\begin{array}{l}\text { Chedung Level } \\
\text { Moraine (G5) }\end{array}$ & I (Ghasa stage) & $\begin{array}{c}\text { Jilong } \\
\text { moraine } \\
\text { (Qomolangma I } \\
\text { and II glaciation) }\end{array}$ & Rongbuk moraine & & & & & \\
\hline \multirow[t]{2}{*}{ Pre-LGM } & & & & & $\begin{array}{l}\text { Jilong Moraine } \\
\text { (no age } \\
\text { assignment) }\end{array}$ & $\mathrm{T} 3$ & $\begin{array}{c}\text { Jilong moraine } \\
\text { (Qomolangma II } \\
\text { glaciation) }\end{array}$ & $24.3 \pm 3.8$ & $26.5 \pm 1.6$ \\
\hline & & & & & & $\mathrm{T} 2$ & $\begin{array}{l}\text { Dzakar moraines } \\
\text { (Qomolangma I } \\
\text { glaciation) }\end{array}$ & $34.6 \pm 6.6$ & $\begin{array}{l}\geq 41.1 \pm 2.3 \\
\geq 38.3 \pm 2.1 \\
\geq 39.4 \pm 1.9\end{array}$ \\
\hline MIS 6 & & & $\begin{array}{l}\text { Older glacier } \\
\text { remnants }\end{array}$ & $\begin{array}{l}\text { Unnamed lower } \\
\text { moraines at } \\
\text { Rongpudoi } \\
\text { (Qomolangma II } \\
\text { glaciation) }\end{array}$ & & & & & \\
\hline Pre-MIS 6 & & $\begin{array}{l}\text { Nyanyaxungla } \\
\text { glaciations } \\
\text { Xixabangma } \\
\text { glaciation }\end{array}$ & & $\begin{array}{l}\text { Unnamed higher } \\
\text { moraines at } \\
\text { Rongpudoi } \\
\text { (Qomolangma I } \\
\text { glaciation) }\end{array}$ & & $\mathrm{T} 1$ & Tingri moraine & $330 \pm 29$ & \\
\hline
\end{tabular}


Table 3

Equivalent dose $\left(\mathrm{D}_{\mathrm{e}}\right)$ data, dose-rates and OSL ages for 180-212 $\mu \mathrm{m}$ quartz.

\begin{tabular}{|c|c|c|c|c|c|c|c|c|c|c|c|c|c|c|}
\hline $\begin{array}{l}\text { Sample } \\
\text { number }\end{array}$ & $\begin{array}{l}\text { Relative } \\
\text { age }\end{array}$ & Moraine & $\begin{array}{l}\text { Depositional } \\
\text { environment }\end{array}$ & Latitude/Longitude & $\begin{array}{l}\text { Altitude } \\
\text { (m asl) }\end{array}$ & $\begin{array}{c}\mathrm{U} \\
(\mathrm{ppm})\end{array}$ & $\begin{array}{c}\text { Th } \\
(\mathrm{ppm})\end{array}$ & $\begin{array}{c}\mathrm{K} \\
(\%)\end{array}$ & $\begin{array}{c}\mathrm{H}_{2} \mathrm{O} \\
\text { content }{ }^{1} \\
(\%)\end{array}$ & $\begin{array}{c}\text { Cosmic } \\
\text { dose-rate }^{2} \\
\left(\mathrm{mGya}^{-1}\right)\end{array}$ & $\mathrm{N}^{3}$ & $\begin{array}{c}\text { Total dose } \\
\text { rate } \\
\left(\mathrm{mGya}^{-1}\right)\end{array}$ & $\begin{array}{c}D_{e} \\
\text { (Gy) }\end{array}$ & $\begin{array}{c}\mathrm{Age}^{4} \\
(\mathrm{ka})\end{array}$ \\
\hline OSL-9 & $\mathrm{T} 5 \mathrm{c}$ & Samdupo & supraglacial-glaciofluvial & $28.1453^{\circ} \mathrm{N} \quad 86.8497^{\circ} \mathrm{E}$ & 5160 & $7.28 \pm 0.18$ & $11.96 \pm 0.33$ & $2.86 \pm 0.04$ & 2.5 & 0.3196 & 36 & $5.65 \pm 0.16$ & $12.8 \pm 0.6$ & $2.3 \pm 0.1$ \\
\hline OSL-13 & T5a & Samdupo & glaciofluvial & $28.1516^{\circ} \mathrm{N} \quad 86.8451^{\circ} \mathrm{E}$ & 5142 & $7.06 \pm 0.18$ & $12.07 \pm 0.33$ & $3.00 \pm 0.04$ & 9.3 & 0.3627 & 22 & $5.78 \pm 0.16$ & $39.2 \pm 3.1$ & $6.8 \pm 0.6$ \\
\hline OSL-12 & T5a & Samdupo & abation valley fill & $28.1299^{\circ} \mathrm{N} \quad 86.8617^{\circ} \mathrm{E}$ & 5320 & $5.10 \pm 0.16$ & $12.52 \pm 0.34$ & $2.47 \pm 0.03$ & 23.2 & 0.4123 & 20 & $4.89 \pm 0.16$ & $33.3 \pm 2.2$ & $6.8 \pm 0.5$ \\
\hline OSL-6 & T5a & Samdupo & glaciofluvial & $28.1534^{\circ} \mathrm{N} \quad 86.8502^{\circ} \mathrm{E}$ & 5026 & $9.06 \pm 0.20$ & $12.30 \pm 0.34$ & $2.98 \pm 0.04$ & 3 & 0.4219 & 21 & $6.30 \pm 0.17$ & $48.8 \pm 1.6$ & $7.7 \pm 0.3$ \\
\hline OSL-7 & Post-T2 -PreT5a & Samdupo & glaciofluvial & $28.1524^{\circ} \mathrm{N} 86.8501^{\circ} \mathrm{E}$ & 5134 & $8.27 \pm 0.19$ & $10.98 \pm 0.32$ & $2.98 \pm 0.04$ & 0.3 & 0.2366 & 19 & $5.84 \pm 0.16$ & $239.9 \pm 11.9$ & $41.1 \pm 2.3$ \\
\hline OSL22 & $\mathrm{T} 4$ & Rongbuk & glaciofluvial & $28.2090^{\circ} \mathrm{N} 86.8200^{\circ} \mathrm{E}$ & 4909 & $4.93 \pm 0.16$ & $13.40 \pm 0.35$ & $2.58 \pm 0.04$ & 2.0 & 0.4245 & 25 & $5.03 \pm 0.16$ & $71.6 \pm 3.9$ & $14.2 \pm 0.9$ \\
\hline OSL-1 (single aliquot) & $\mathrm{T} 4$ & Rongbuk & glaciofluvial & $28.2045^{\circ} \mathrm{N} 86.8245^{\circ} \mathrm{E}$ & 5010 & $6.55 \pm 0.18$ & $13.19 \pm 0.35$ & $2.64 \pm 0.04$ & 1.9 & 0.3934 & 39 & $5.42 \pm 0.16$ & $83.9 \pm 2.3$ & $15.5 \pm 0.6$ \\
\hline OSL-1 (single grain) & -- & -- & -- & -- & -- & -- & -- & -- & -- & -- & 30 & -- & $94.3 \pm 10.4(84.9)^{5}$ & $17.5 \pm 2.0$ \\
\hline OSL-17 (St Andrews) & $\mathrm{T} 4$ & Rongbuk & deformed proglacial & $28.1860^{\circ} \mathrm{N} 86.8320^{\circ} \mathrm{E}$ & 4982 & $3.42 \pm 0.14$ & $11.33 \pm 0.32$ & $2.10 \pm 0.03$ & 0.8 & 0.2560 & 36 & $3.90 \pm 0.16$ & $63.6 \pm 1.7$ & $16.3 \pm 0.8$ \\
\hline OSL-17 (Aarhus) & - & - & -- & -- & - & -- & -- & -- & -- & -- & 22 & -- & $65.4 \pm 14$ & $16.8 \pm 0.8$ \\
\hline OSL-2 & Post T2 - Pre-T4 & Rongbuk & glaciofluvial & $28.2038^{\circ} \mathrm{N} 86.8244^{\circ} \mathrm{E}$ & 5003 & $5.08 \pm 0.16$ & $12.35 \pm 0.33$ & $2.61 \pm 0.04$ & 2.9 & 0.3723 & 32 & $4.97 \pm 0.16$ & $190.3 \pm 8.2$ & $38.3 \pm 2.1$ \\
\hline OSL-5 & Post-T3 & Jilong & alluvial fan & $28.2536^{\circ} \mathrm{N} 86.8229^{\circ} \mathrm{E}$ & 4909 & $4.00 \pm 0.16$ & $15.14 \pm 0.37$ & $2.57 \pm 0.04$ & 2.3 & 0.3694 & 13 & $4.86 \pm 0.16$ & $56.7 \pm 2.6$ & $11.7 \pm 0.7$ \\
\hline OSL-4 & Post-T3 & Jilong & alluvial fan & $28.2528^{\circ} \mathrm{N} 86.8229^{\circ} \mathrm{E}$ & 4905 & $4.73 \pm 0.17$ & $15.64 \pm 0.38$ & $2.84 \pm 0.04$ & 2.7 & 0.4127 & 31 & $5.37 \pm 0.16$ & $70.4 \pm 3.1$ & $13.1 \pm 0.7$ \\
\hline OSL-10 & $\mathrm{T} 3$ & Jilong & supraglacial & $28.2523^{\circ} \mathrm{N} 86.8248^{\circ} \mathrm{E}$ & 4919 & $4.40 \pm 0.16$ & $14.83 \pm 0.37$ & $2.59 \pm 0.04$ & 17.3 & 0.4110 & 29 & $5.00 \pm 0.16$ & $132.4 \pm 6.7$ & $26.5 \pm 1.6$ \\
\hline OSL-15 & Post-T2 - Pre-T3 & Jilong & glaciofluvial & $28.2444^{\circ} \mathrm{N} 86.8195^{\circ} \mathrm{E}$ & 4839 & $6.88 \pm 0.18$ & $12.93 \pm 0.34$ & $2.38 \pm 0.04$ & 4.7 & 0.3042 & 32 & $5.13 \pm 0.16$ & $202.7 \pm 7.1$ & $39.4 \pm 1.9$ \\
\hline
\end{tabular}

${ }^{1}$ Percent moisture compared to dry weight. Uncertainty taken as $5 \%$.

${ }^{2}$ Cosmic dose-rate calculated assuming constant burial depth using method described in Prescott and Hutton (1994). Uncertainty taken as $10 \%$.

${ }^{3}$ Number of replicated $D_{\mathrm{e}}$ estimates.

${ }^{4} \mathrm{D}_{\mathrm{e}}$ and ages calculated using mean $\mathrm{D}_{\mathrm{e}}$.

${ }^{5} \mathrm{D}_{\mathrm{e}}$ values for single grain analysis of OSL-1 reported as mean and median (in brackets) values for comparison with single aliquot $\mathrm{D}_{\mathrm{e}}$ 
Table 4

Data for ${ }^{10} \mathrm{Be}$ TCN surface exposure samples using Lal (1991)/Stone (2000) time-independent scaling model with $0 \mathrm{~m} / \mathrm{Ma}$ erosion

\begin{tabular}{|c|c|c|c|c|c|c|c|c|c|c|c|c|c|c|}
\hline & & Relative & & Boulder size & & Weathering & & & & & & & ${ }^{10} \mathrm{Be}$ & \\
\hline & Sampling site/type & & $\begin{array}{l}\text { Length } \\
(\mathrm{cm})\end{array}$ & $\begin{array}{l}\text { Width } \\
(\mathrm{cm})\end{array}$ & $\begin{array}{l}\text { Height } \\
(\mathrm{cm})\end{array}$ & & Lithology & & & & & correction & $\begin{array}{l}\left(10^{6}\right. \\
\text { atoms/g SiO }\end{array}$ & (ka) \\
\hline Ron51 & supraglacial boulder & $\mathrm{T} 7$ & 120 & 140 & 80 & SW/MB & leucogranite & 28.1298 & 86.8531 & 5216 & 3.5 & 0.97 & $0.011 \pm 0.008$ & $0.1 \pm 0.1$ \\
\hline Ron52 & supraglacial debris & $\mathrm{T} 7$ & & $\begin{array}{l}\text { sedimment } \\
\text { sample }\end{array}$ & & NW/P & sediment & 28.1296 & 86.8535 & 5223 & 5.0 & 1.00 & $0.012 \pm 0.002$ & $0.1 \pm 0.0$ \\
\hline Ron53 & supraglacial boulder & $\mathrm{T} 7$ & 230 & 170 & 90 & NW & leucogranite & 28.1294 & 86.8542 & 5213 & 2.3 & 0.97 & $0.020 \pm 0.002$ & $0.2 \pm 0.0$ \\
\hline Ron54 & supraglacial debris & $\mathrm{T} 7$ & & $\begin{array}{l}\text { seciment } \\
\text { sample }\end{array}$ & & NW/SB & sediment & 28.1294 & 86.8542 & 5187 & 4.0 & 1.00 & $0.024 \pm 0.002$ & $0.3 \pm 0.0$ \\
\hline Ron55 & supraglacial boulder & $\mathrm{T} 7$ & 540 & 350 & 260 & $\mathrm{NW}$ & leucogranite & 28.1296 & 86.8560 & 5225 & 2.0 & 0.97 & $0.039 \pm 0.003$ & $0.4 \pm 0.1$ \\
\hline Ron56 & supraglacial debris & $\mathrm{T} 7$ & & $\begin{array}{l}\text { sediment } \\
\text { sample }\end{array}$ & & NW/WB & sediment & 28.1296 & 86.8560 & 5228 & 5.0 & 1.00 & $0.050 \pm 0.002$ & $0.6 \pm 0.1$ \\
\hline Ron57 & supraglacial debris & $\mathrm{T} 7$ & & $\begin{array}{l}\text { sedment } \\
\text { sample }\end{array}$ & & $\mathrm{NW}$ & sediment & 28.1293 & 86.8582 & 5238 & 4.0 & 1.00 & $0.027 \pm 0.002$ & $0.3 \pm 0.0$ \\
\hline Ron58 & supraglacial debris & $\mathrm{T} 7$ & & $\begin{array}{l}\text { sediment } \\
\text { sample }\end{array}$ & & MW & sediment & 28.1298 & 86.8574 & 5220 & 4.0 & 1.00 & $0.029 \pm 0.003$ & $0.3 \pm 0.0$ \\
\hline Ron59 & outwash stream sediment & $\mathrm{T} 7$ & & $\begin{array}{l}\text { sediment } \\
\text { sample }\end{array}$ & & NW & sediment & 28.1340 & 86.8537 & 5175 & 5.0 & 1.00 & $0.037 \pm 0.003$ & $0.4 \pm 0.1$ \\
\hline Ron61 & Xarlungnama moraine & T6 & 140 & 80 & 40 & $\mathrm{NW}$ & leucogranite & 28.1363 & 86.8515 & 5175 & 1.5 & 0.98 & $0.143 \pm 0.005$ & $1.6 \pm 0.2$ \\
\hline Ron62 & Xarlungnama moraine & T6 & 300 & 280 & 60 & SW/MB & leucogranite & 28.1364 & 86.8515 & 5178 & 5.0 & 0.98 & $0.129 \pm 0.004$ & $1.5 \pm 0.1$ \\
\hline Ron63 & Xarlungnama moraine & T6 & 530 & 470 & 40 & SW/MB & leucogranite & 28.1364 & 86.8515 & 5174 & 2.5 & 0.98 & $0.139 \pm 0.007$ & $1.6 \pm 0.2$ \\
\hline Ron34 & Samdupo hummocky moriane & T5b & 260 & 240 & 100 & sw/wB & leucogranite & 28.1456 & 86.8500 & 5176 & 1.5 & 0.97 & $0.161 \pm 0.006$ & $1.8 \pm 0.2$ \\
\hline Ron35 & Samdupo hummocky moriane & T5b & 430 & 340 & 115 & SW/MB & leucogranite & 28.1465 & 86.8483 & 5180 & 1.5 & 0.97 & $0.116 \pm 0.005$ & $1.3 \pm 0.1$ \\
\hline Ron36 & Samdupo hummocky moriane & T5b & 300 & 220 & 220 & SW/MB & leucogranite & 28.1465 & 86.8484 & 5164 & 3.0 & 0.96 & $0.109 \pm 0.005$ & $1.3 \pm 0.1$ \\
\hline Ron25 & Samdupo moraine & $\mathrm{T} 5 \mathrm{c}$ & 95 & 95 & 75 & SW/MB & leucogranite & 28.1423 & 86.8536 & 5242 & 2.5 & 0.98 & $0.200 \pm 0.010$ & $2.2 \pm 0.2$ \\
\hline Ron26 & Samdupo moraine & T5c & 200 & 160 & 70 & NW/SB & leucogranite & 28.1424 & 86.8535 & 5240 & 3.5 & 0.98 & $0.221 \pm 0.007$ & $2.5 \pm 0.2$ \\
\hline Ron27 & Samdupo moraine & $\mathrm{T} 5 \mathrm{c}$ & 180 & 113 & 52 & NW/SB & leucogranite & 28.1427 & 86.8540 & 5247 & 5.0 & 0.98 & $0.080 \pm 0.006$ & $0.9 \pm 0.1$ \\
\hline Ron28 & Samdupo moraine & T5c & 210 & 100 & 65 & sw/sB & leucogranite & 28.1431 & 86.8544 & 5244 & 3.0 & 0.98 & $0.230 \pm 0.010$ & $2.6 \pm 0.2$ \\
\hline Ron29 & Samdupo moraine & $\mathrm{T} 5 \mathrm{c}$ & 290 & 150 & 150 & $\mathrm{NW/SB}$ & leucogranite & 28.1432 & 86.8539 & 5240 & 1.0 & 0.98 & $0.197 \pm 0.011$ & $2.2 \pm 0.2$ \\
\hline Ron30 & Samdupo moraine & $\mathrm{T} 5 \mathrm{c}$ & 170 & 120 & 50 & sw/wB & leucogranite & 28.1436 & 86.8540 & 5245 & 3.0 & 0.98 & $0.206 \pm 0.010$ & $2.3 \pm 0.2$ \\
\hline Ron31 & Samdupo moraine (mid slope) & T5c & 200 & 200 & 130 & NW/SB & leucogranite & 28.1432 & 86.8523 & 5193 & 4.5 & 0.95 & $0.084 \pm 0.006$ & $1.0 \pm 0.1$ \\
\hline Ron32 & Samdupo moraine (mid slope) & T5c & 140 & 140 & 100 & $\mathrm{sW} / \mathrm{WB}$ & leucogranite & 28.1432 & 86.8523 & 5190 & 0.5 & 0.95 & $0.081 \pm 0.008$ & $0.9 \pm 0.1$ \\
\hline Ron33 & Samdupo moraine (mid slope) & TSc & 110 & 80 & 100 & $\mathrm{sW} / \mathrm{WB}$ & leucogranite & 28.1428 & 86.8523 & 5195 & 1.0 & 0.96 & $0.094 \pm 0.005$ & $1.1 \pm 0.1$ \\
\hline Ron2 & Rongbuk moraine & T4 & 120 & 60 & 55 & SW/DB & leucogranite & 28.2032 & 86.8263 & 5041 & 4.0 & 0.97 & $1.205 \pm 0.029$ & $15.0 \pm 1.4$ \\
\hline Ron3 & Rongbuk moraine & T4 & 150 & 115 & 45 & NWMB & leucogranite & 28.2034 & 86.8263 & 5056 & 1.0 & 0.97 & $1.255 \pm 0.051$ & $15.1+1.5$ \\
\hline
\end{tabular}




\begin{tabular}{|c|c|c|c|c|c|c|c|c|c|c|c|c|c|c|}
\hline Ron4 & Rongbuk moraine & T4 & 85 & 70 & 55 & SW/MB & foliated granite & 28.2033 & 86.8263 & 5064 & 4.0 & 0.97 & $1.241 \pm 0.031$ & $15.3 \pm 1.4$ \\
\hline Ron5 & Rongbuk moraine & T4 & 95 & 70 & 55 & SW/MB & leucogranite & 28.2035 & 86.8261 & 5057 & 2.3 & 0.98 & $1.206 \pm 0.029$ & $14.6 \pm 1.3$ \\
\hline Ron6 & Rongbuk moraine & T4 & 125 & 70 & 110 & NW/MB & leucogranite & 28.2039 & 86.8256 & 5055 & 3.0 & 0.98 & $1.197 \pm 0.030$ & $14.5 \pm 1.3$ \\
\hline Ron7 & Rongbuk moraine & T4 & 160 & 100 & 70 & NW/MB & leucogranite & 28.2041 & 86.8255 & 5045 & 4.0 & 0.98 & $1.737 \pm 0.039$ & $21.4 \pm 1.9$ \\
\hline Ron8 & Rongbuk moraine & T4 & 160 & 170 & 140 & NW/MB & leucogranite & 28.2045 & 86.8253 & 5036 & 3.0 & 0.98 & $2.007 \pm 0.048$ & $24.6 \pm 2.2$ \\
\hline Ron9 & Rongbuk moraine & T4 & 100 & 75 & 55 & MW/MB & quartzite sampled & 28.2045 & 86.8253 & 5031 & 3.0 & 0.98 & $1.015 \pm 0.038$ & $12.4 \pm 1.2$ \\
\hline Ron10 & Rongbuk moraine (mid slope) & T4 & 200 & 180 & 50 & SW/MB & foliated leucogranite & 28.2033 & 86.8257 & 5027 & 2.5 & 0.97 & $1.184 \pm 0.031$ & $14.7 \pm 1.3$ \\
\hline Ron11 & Rongbuk moraine (mid slope) & T4 & 210 & 150 & 65 & SW/MB & pegmatitic granite & 28.2025 & 86.8263 & 5044 & 2.5 & 0.96 & $0.947 \pm 0.024$ & $11.8 \pm 1.1$ \\
\hline Ron 12 & Rongbuk moraine (mid slope) & T4 & 225 & 120 & 50 & HW/WB & foliated leucogranite & 28.2022 & 86.8267 & 5044 & 3.0 & 0.95 & $7.614 \pm 0.121$ & $97.3 \pm 8.8$ \\
\hline Ron13 & Rongbuk moraine (mid slope) & T4 & 120 & 100 & 50 & NW/MB & leucogranite & 28.2021 & 86.8267 & 5057 & 1.5 & 0.95 & $0.900 \pm 0.022$ & $11.1 \pm 1.0$ \\
\hline Ron64 & Jilong (Surprise) moraine & T3' & 155 & 130 & 110 & SW/MB & leucogranite & 28.2029 & 86.8288 & 5195 & 1.5 & 0.95 & $1.560 \pm 0.038$ & $18.2 \pm 1.7$ \\
\hline Ron65 & Jilong (Surprise) moraine & T3' & 90 & 70 & 60 & SW/MB & leucogranite & 28.2029 & 86.8288 & 5199 & 2.5 & 0.95 & $1.483 \pm 0.036$ & $17.5 \pm 1.6$ \\
\hline Ron66 & Jilong (Surprise) moraine & T3' & 150 & 100 & 110 & SW/DB & leucogranite & 28.2028 & 86.8288 & 5199 & 1.5 & 0.95 & $1.448 \pm 0.040$ & $16.9 \pm 1.5$ \\
\hline Ron67 & Jilong (Surprise) moraine & T3' & 175 & 130 & 90 & NW/MB & leucogranite & 28.2028 & 86.8288 & 5199 & 2.0 & 0.95 & $1.468 \pm 0.037$ & $17.2 \pm 1.6$ \\
\hline Ron14 & Jilong moraine & Т3 & 120 & 110 & 94 & $\mathrm{HW} / \mathrm{DB}$ & leucogranite & 28.2510 & 86.8243 & 4959 & 5.0 & 1.00 & $2.237 \pm 0.040$ & $28.4 \pm 2.5$ \\
\hline Ron15 & Jilong moraine & Тз & 140 & 80 & 75 & MW/DB & leucogranite & 28.2510 & 86.8243 & 4954 & 2.8 & 1.00 & $1.822 \pm 0.045$ & $22.7 \pm 2.1$ \\
\hline Ron16 & Jilong moraine & Тз & 155 & 115 & 85 & HW/SB & leucogranite & 28.2510 & 86.8243 & 4957 & 2.0 & 1.00 & $2.197 \pm 0.067$ & $27.2 \pm 2.5$ \\
\hline Ron17 & Jilong moraine & Т3 & 240 & 215 & 135 & HW/SB & pegmatitic leucogranite & 28.2509 & 86.8243 & 4958 & 1.5 & 1.00 & $1.819 \pm 0.045$ & $22.4 \pm 2.0$ \\
\hline Ron18 & Jilong moraine & Т3 & 100 & 90 & 90 & HWMB & leucogranite & 28.2509 & 86.8243 & 4962 & 3.0 & 1.00 & $1.891 \pm 0.033$ & $23.5 \pm 2.1$ \\
\hline Ron19a & Jilong moraine & Т3 & 420 & 330 & 175 & NW/MB & leucogranite & 28.2513 & 86.8236 & 4935 & 4.0 & 1.00 & $1.409 \pm 0.034$ & $17.8 \pm 1.6$ \\
\hline Ron20 & Jilong moraine & Т3 & 750 & 500 & 220 & SW/MB & leucogranite & 28.2514 & 86.8235 & 4935 & 5.0 & 1.00 & $2.020 \pm 0.047$ & $25.8 \pm 2.3$ \\
\hline Ron21 & Jilong moraine & T3 & 630 & 420 & 130 & HWMB & leucogranite & 28.2514 & 86.8237 & 4943 & 4.0 & 1.00 & $2.049 \pm 0.036$ & $25.9 \pm 2.3$ \\
\hline Ron22 & Jilong moraine & T3 & 520 & 420 & 240 & HW/MB & leucogranite & 28.2517 & 86.8235 & 4933 & 0.5 & 1.00 & $1.464 \pm 0.036$ & $18.0 \pm 1.6$ \\
\hline Ron23 & Jilong moraine & T3 & 600 & 450 & 300 & HW/DB & leucogranite & 28.2517 & 86.8235 & 4921 & 4.0 & 1.00 & $2.067 \pm 0.065$ & $26.4 \pm 2.4$ \\
\hline Ron24 & Jilong moraine & T3 & 370 & 240 & 90 & NW/MB & leucogranite & 28.2522 & 86.8238 & 4927 & 4.0 & 1.00 & $2.266 \pm 0.040$ & $28.8 \pm 2.6$ \\
\hline Ron37 & Dzakar moraine & T2 & 240 & 150 & 75 & SW/MB & leucogranite & 28.2551 & 86.8248 & 5003 & 0.5 & 1.00 & $2.493 \pm 0.038$ & $29.8 \pm 2.6$ \\
\hline Ron38 & Dzakar moraine & T2 & 130 & 100 & 80 & HW/MB & leucogranite & 28.2551 & 86.8248 & 5003 & 0.5 & 1.00 & $2.570 \pm 0.046$ & $30.7 \pm 2.7$ \\
\hline Ron40 & Dzakar moraine & T2 & 95 & 80 & 70 & HW/SB & leucogranite & 28.2550 & 86.8247 & 5002 & 2.0 & 1.00 & $2.567 \pm 0.048$ & $31.1 \pm 2.8$ \\
\hline Ron41 & Dzakar moraine & T2 & 195 & 90 & 100 & HW/SB & leucogranite & 28.2554 & 86.8247 & 5007 & 3.0 & 1.00 & $3.909 \pm 0.115$ & $47.8 \pm 4.4$ \\
\hline Ron42 & Dzakar moraine & T2 & 115 & 50 & 40 & HW/MB & leucogranite & 28.2553 & 86.8247 & 5009 & 2.0 & 1.00 & $2.970 \pm 0.048$ & $35.9 \pm 3.2$ \\
\hline Ron43 & Dzakar moraine & T2 & 110 & 80 & 30 & HW/MB & leucogranite & 28.2552 & 86.8247 & 5008 & 2.0 & 1.00 & $2.647 \pm 0.084$ & $32.0 \pm 3.0$ \\
\hline Ron44 & Dzakar moraine & T2 & 100 & 50 & 50 & MW/MB & leucogranite & 28.2552 & 86.8247 & 5004 & 2.0 & 1.00 & $3.355 \pm 0.066$ & $40.7 \pm 3.7$ \\
\hline Ron45 & Dzakar moraine & T2 & & bedrock & & HW/MB & phyllite & 28.2553 & 86.8247 & 5004 & 3.0 & 1.00 & $2.340 \pm 0.056$ & $28.5 \pm 2.6$ \\
\hline Ron46 & Tingri moraine & $\mathrm{T} 1$ & & bedrock & & HW & quartzite & 28.2566 & 86.8341 & 5226 & 3.0 & 1.00 & $19.708 \pm 0.206$ & $228.5 \pm 21.0$ \\
\hline
\end{tabular}




\begin{tabular}{|c|c|c|c|c|c|c|c|c|c|c|c|c|c|c|}
\hline Ron47 & Tingri moraine & $\mathrm{T} 1$ & & bedrock & & HW & quartzite & 28.2560 & 86.8294 & 5123 & 3.0 & 1.00 & $9.919 \pm 0.155$ & $117.2 \pm 10.6$ \\
\hline Ron48 & Tingri moraine & $\mathrm{T} 1$ & 100 & 80 & 35 & HW & quartzite breccia & 28.2560 & 86.8295 & 5133 & 3.0 & 1.00 & $29.058 \pm 0.250$ & $361.3 \pm 34.3$ \\
\hline Ron49 & Tingri moraine & $\mathrm{T} 1$ & 85 & 65 & 25 & $\mathrm{HW} / \mathrm{WB}$ & quartzite breccia & 28.2531 & 86.8304 & 5114 & 1.5 & 1.00 & $26.574 \pm 0.229$ & $326.4 \pm 30.7$ \\
\hline Ron50 & Tingri moraine & $\mathrm{T} 1$ & 70 & 60 & 30 & NW/MB & quartzite breccia & 28.2531 & 86.8304 & 5113 & 1.0 & 1.00 & $24.896 \pm 0.215$ & $303.1 \pm 28.4$ \\
\hline Ron68 & Landslide & post T4 & 90 & 50 & 40 & SW/MB & leucogranite & 28.2023 & 86.8235 & 5028 & 1.5 & 0.99 & $0.712 \pm 0.021$ & $8.6 \pm 0.8$ \\
\hline Ron69 & Landslide & post T4 & 115 & 65 & 40 & SW/MB & leucogranite & 28.2024 & 86.8236 & 5013 & 1.0 & 0.99 & $0.729 \pm 0.019$ & $8.8 \pm 0.8$ \\
\hline Ron70 & Landslide & post T4 & 120 & 60 & 15 & SW/MB & leucogranite & 28.2024 & 86.8235 & 5009 & 3.0 & 0.99 & $0.667 \pm 0.017$ & $8.2 \pm 0.7$ \\
\hline Ron71 & Landslide & post T4 & 230 & 150 & 150 & MW/WB & leucogranite & 28.2019 & 86.8235 & 5015 & 2.5 & 0.97 & $0.700 \pm 0.014$ & $8.6 \pm 0.8$ \\
\hline Ron72 & Landslide & post T4 & 230 & 180 & 65 & $\mathrm{sw} / \mathrm{wB}$ & $\begin{array}{c}\text { augen gneiss } \\
\text { granitit vein in augen }\end{array}$ & 28.2018 & 86.8243 & 5031 & 4.0 & 0.98 & $0.693 \pm 0.017$ & $8.5 \pm 0.8$ \\
\hline Ron73A & Landslide & post T4 & 380 & 290 & 125 & MW/DB & & 28.2015 & 86.8246 & 5019 & 3.0 & 0.98 & $0.67 \pm \pm 0.018$ & $8.3 \pm 0.8$ \\
\hline Ron73B & Landslide & post T4 & 320 & 180 & 80 & MW/DB & augen gneiss & 28.2015 & 86.8246 & 5019 & 3.0 & 0.98 & $0.700 \pm 0.018$ & $8.6 \pm 0.8$ \\
\hline Ron74 & Old terrace & & 250 & 140 & 60 & SW/DB & leucogranite & 28.2449 & 86.8186 & 4836 & 0.5 & 0.98 & $2.973 \pm 0.064$ & $39.3 \pm 3.5$ \\
\hline Ron75 & Old terrace & & 170 & 170 & 55 & SW/DB & leucogranite & 28.2447 & 86.8186 & 4837 & 1.5 & 0.98 & $1.114 \pm 0.022$ & $14.8 \pm 1.3$ \\
\hline Ron77 & Old terrace & & 460 & 450 & 160 & HW/DB & leucogranite & 28.2443 & 86.8188 & 4841 & 2.0 & 0.98 & $0.766 \pm 0.019$ & $10.2 \pm 0.9$ \\
\hline Ron78 & Old terrace & & 140 & 130 & 70 & $\mathrm{HW} / \mathrm{DB}$ & leucogranite & 28.2453 & 86.8187 & 4838 & 1.8 & 0.98 & $1.240 \pm 0.025$ & $16.5 \pm 1.5$ \\
\hline
\end{tabular}

${ }^{a} \mathrm{NW}$ - not weathered; SW - slightly weathered (granular weathering, but no pits), MW - moderately weathered (granular weathering and slight exfoliation); HW - highly weathered (pitting $>1 \mathrm{~cm}$ deep, cavernous weathering and exfoliation); DB - deeply buried (boulder only slightly exposed above surface); SB - slightly buried (could be easily dug out of the ground); and MB - moderately buried (well inset into substrate).

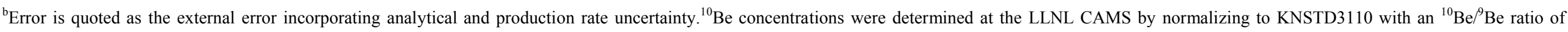
$3.15 \times 10^{-12}$ (Nishiizumi et al., 2007) 
Table 5

Correlation of glacial stages across Mount Everest and former ELAs

\begin{tabular}{|c|c|c|c|c|c|c|}
\hline $\begin{array}{c}\text { Glacial } \\
\text { stages in the } \\
\text { Rongbuk } \\
\text { valley }\end{array}$ & $\begin{array}{l}\text { TCN } \\
\text { Age } \\
(\mathrm{ka})^{*}\end{array}$ & $\begin{array}{l}\text { OSL ages } \\
(\mathrm{ka})^{*}\end{array}$ & $\begin{array}{c}\text { Glacial } \\
\text { stages in the } \\
\text { Khumbu } \\
\text { Himal }\end{array}$ & $\begin{array}{c}\text { TCN ages } \\
(\mathrm{ka})^{*}\end{array}$ & $\begin{array}{l}\text { OSL } \\
\text { ages } \\
(\mathrm{ka})^{*}\end{array}$ & \\
\hline Xarlungnama & $1.6 \pm 0.1$ & & Lobuche & $1.1 \pm 0.4$ & $1.8 \pm 1.0$ & Neoglacial \\
\hline Samdupo II & $2.4 \pm 0.2$ & $2.3 \pm 0.1^{\#}$ & ------- & & & \\
\hline & & & Thukha & $3.5 \pm 0.3$ & & Neoglacial \\
\hline Samdupo I & ------- & $7.1 \pm 0.5$ & -------- & & & \\
\hline & & & Chhukung & $10.1 \pm 0.4$ & $10.0 \pm 0.7$ & $\begin{array}{c}\text { Early } \\
\text { Holocene }\end{array}$ \\
\hline Rongbuk & $16.6 \pm 4.1$ & $15.3 \pm 1.1$ & Periche II & $17.0 \pm 1.7$ & & MIS-2 \\
\hline Jilong & $24.3 \pm 3.8$ & $<38.3 \pm 2.1 \dagger$ & Periche I & $23.9 \pm 2.5$ & $22.2 \pm 2.2$ & MIS-2 \\
\hline Dzakar & $34.6 \pm 6.6$ & $>38.3 \pm 2.1 \dagger$ & $\begin{array}{l}\text { Thyangboche } \\
\text { II }\end{array}$ & $40.0 \pm 5.0$ & & MIS-3 \\
\hline & & & $\begin{array}{c}\text { Thyangboche } \\
\text { I }\end{array}$ & $68.1 \pm 34.6$ & & \\
\hline Tingri & $>330$ & & --------- & & & \\
\hline \multicolumn{7}{|l|}{ Notes: } \\
\hline \multicolumn{7}{|c|}{$*$ Mean and $1 \sigma}$. \\
\hline \# Only one sar & le was da & & & & & \\
\hline
\end{tabular}

Table 6

Former ELAs for selected stages of the Rongbuk and Khumbu Glaciers (based on an AAR of 0.55)

\begin{tabular}{|c|c|c|c|c|c|}
\hline Rongbuk Glacier & $\begin{array}{c}\text { Former } \\
\text { ELA }\end{array}$ & $\triangle \mathrm{ELA}$ & $\begin{array}{l}\text { Khumbu } \\
\text { Glacier }\end{array}$ & $\begin{array}{c}\text { Former } \\
\text { ELA }\end{array}$ & $\Delta \mathrm{ELA}$ \\
\hline $\begin{array}{c}\text { Present } \\
\text { (estimate) }\end{array}$ & 6200 & & $\begin{array}{c}\text { Present } \\
\text { (estimate) }\end{array}$ & 5700 & \\
\hline Samdupo I & 6140 & 60 & Mid-Holocene & 5660 & 40 \\
\hline Rongbuk & 6100 & 100 & Periche II & 5430 & 270 \\
\hline Jilong & 6050 & 150 & Periche I* & 5420 & 280 \\
\hline
\end{tabular}

Notes:

* Due to differences in the glacier contouring procedure, the calculated ELA for the Periche I stage is $20 \mathrm{~m}$ higher than that reconstructed by Richards et al. (2000b). For consistency with the other results, we have used the revised value. 
A)

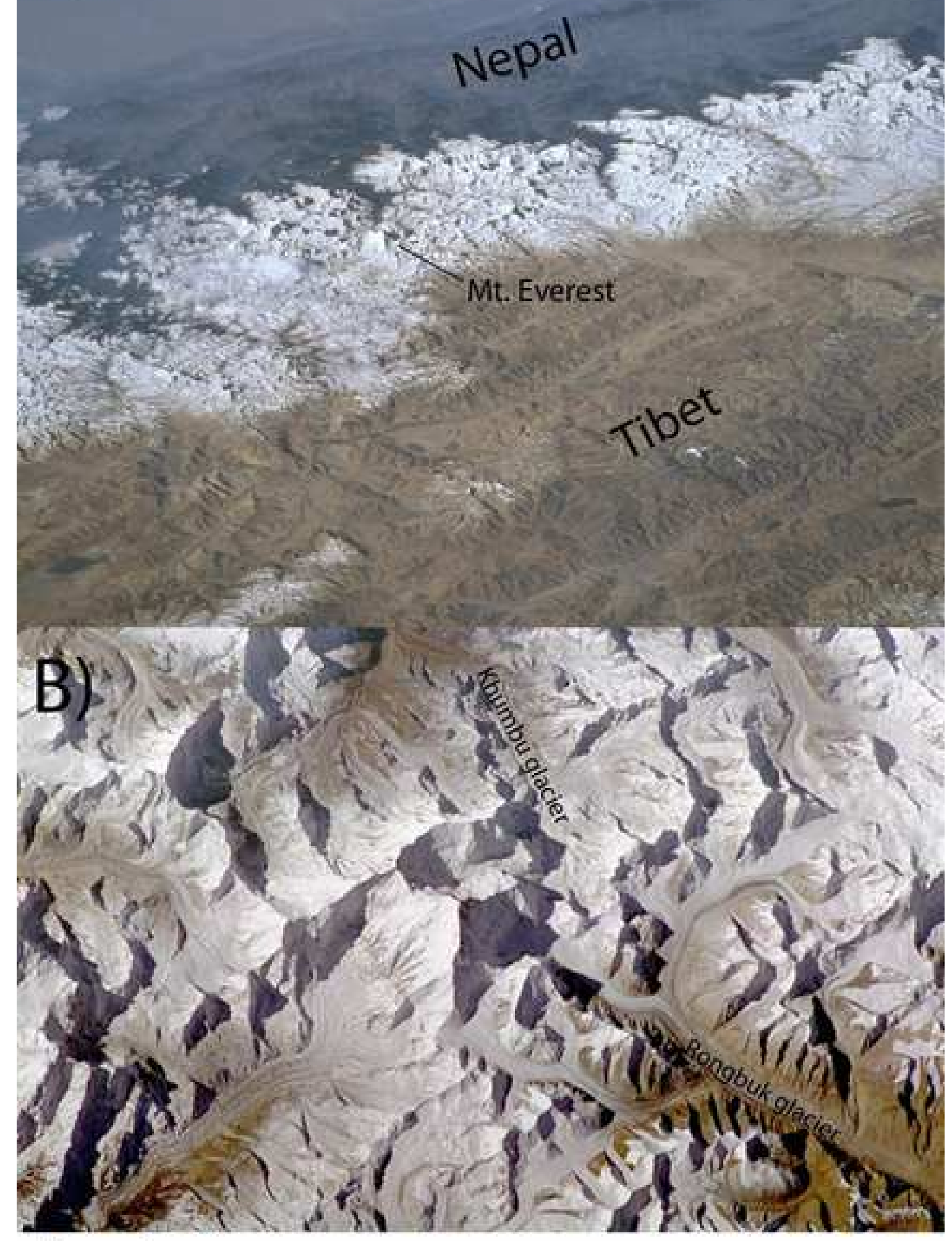

Figure 1 


\section{Figure 2}

Click here to download high resolution image

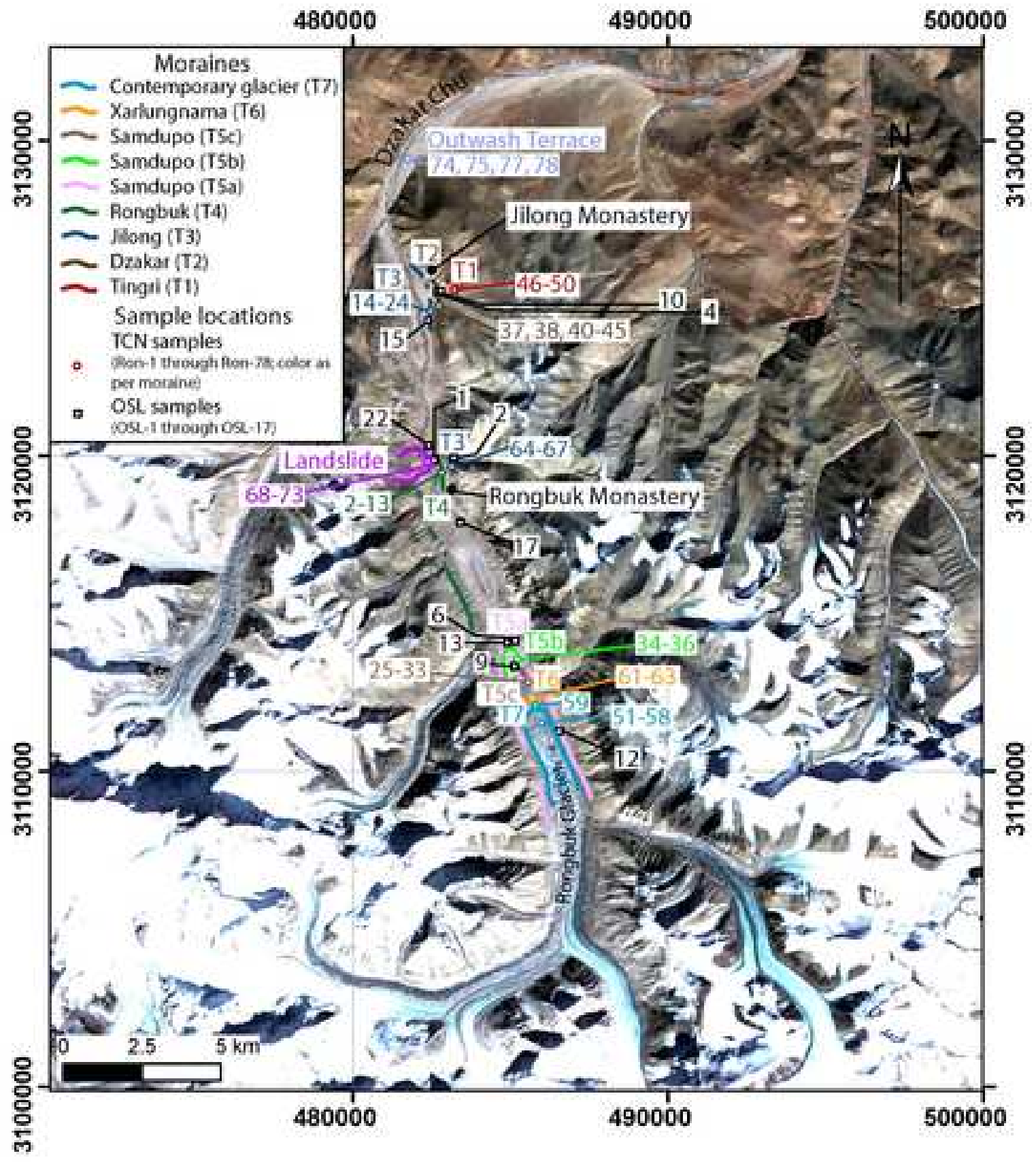

Figure 2 


\section{gure 3}

Click here to download high resolution image

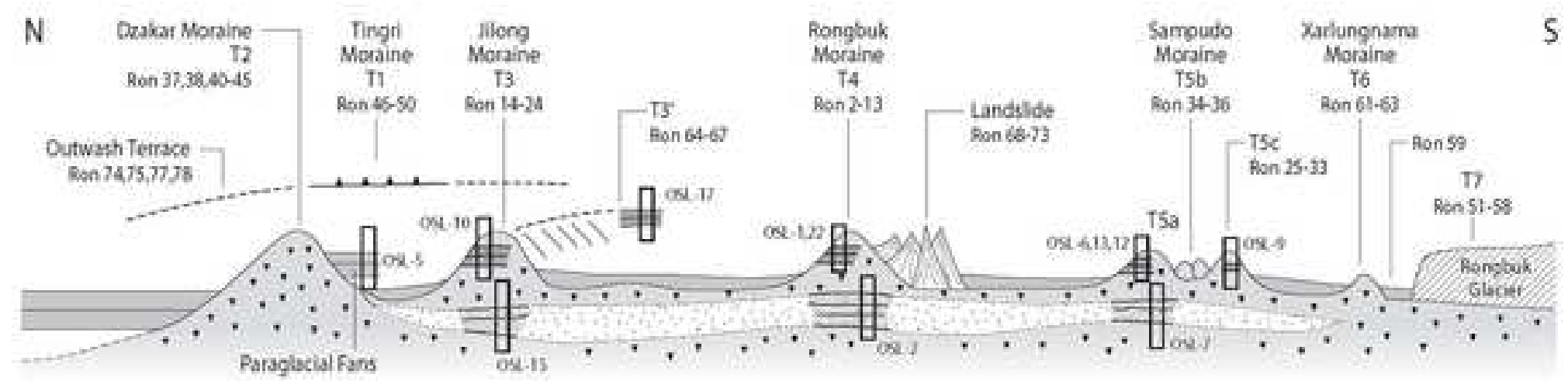

Eutwash redimont

$\equiv$ Dake outisah

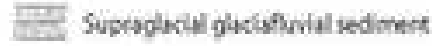

$\because$ Tाіा

S50.ing ave $3 \mathrm{~km}$
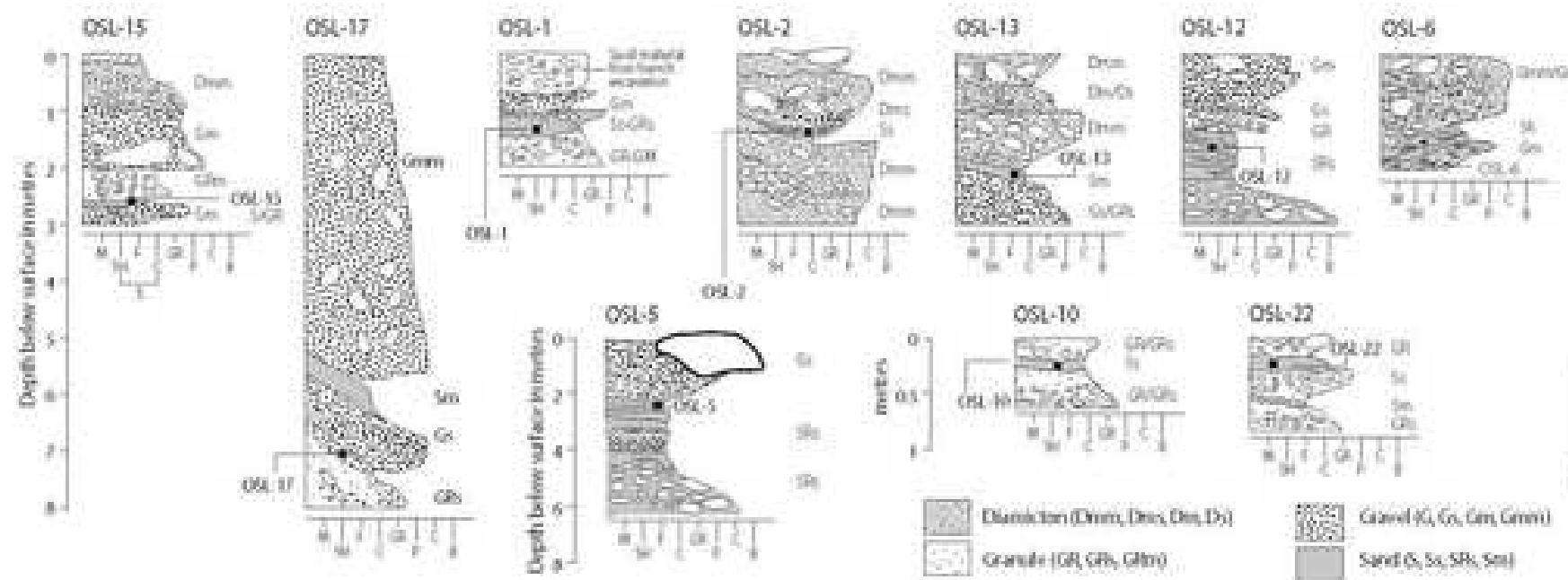

054.22

ferpoum an

ixis?

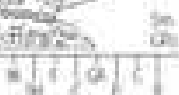

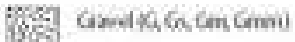

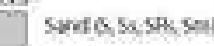

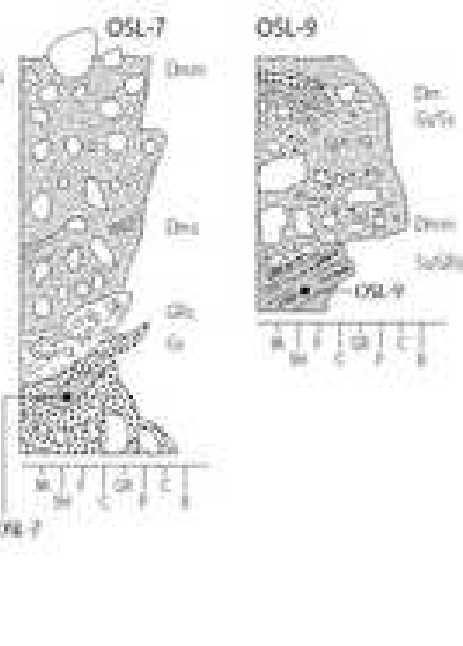


Click here to download high resolution image

A
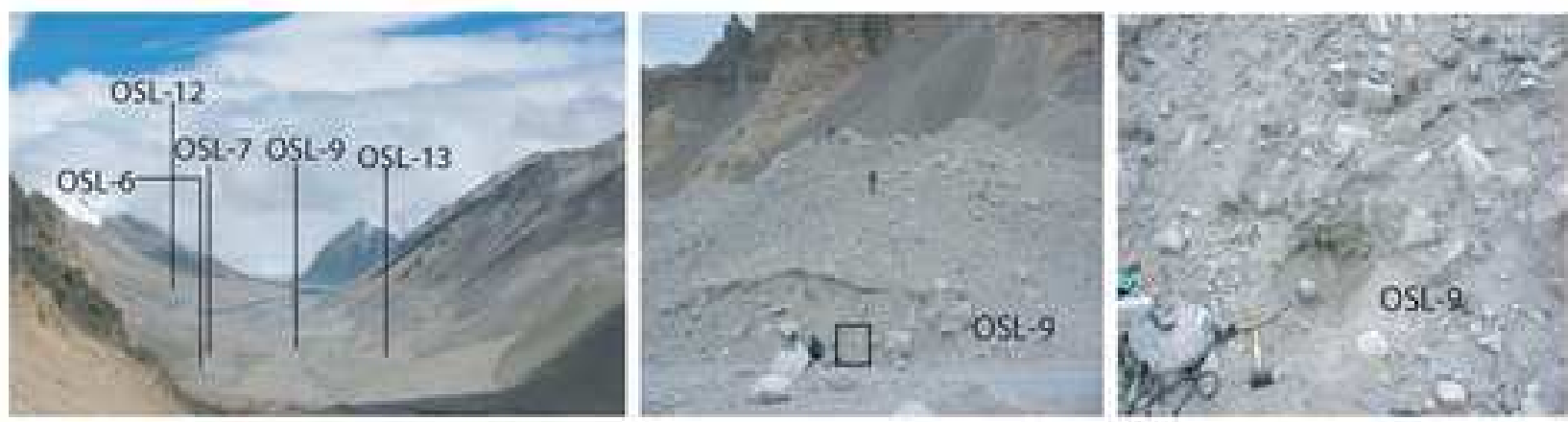

B
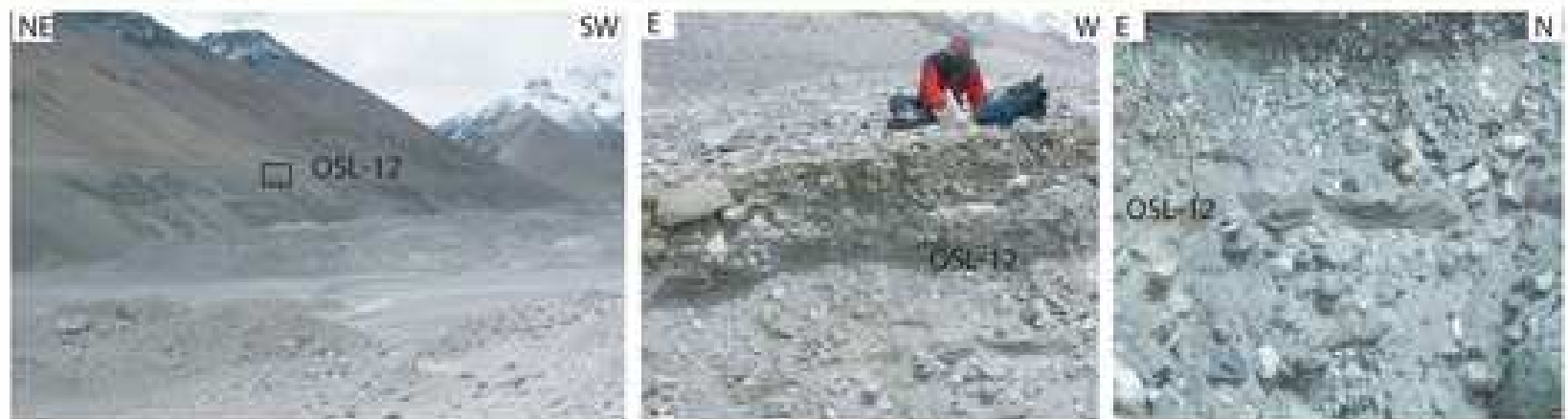

C
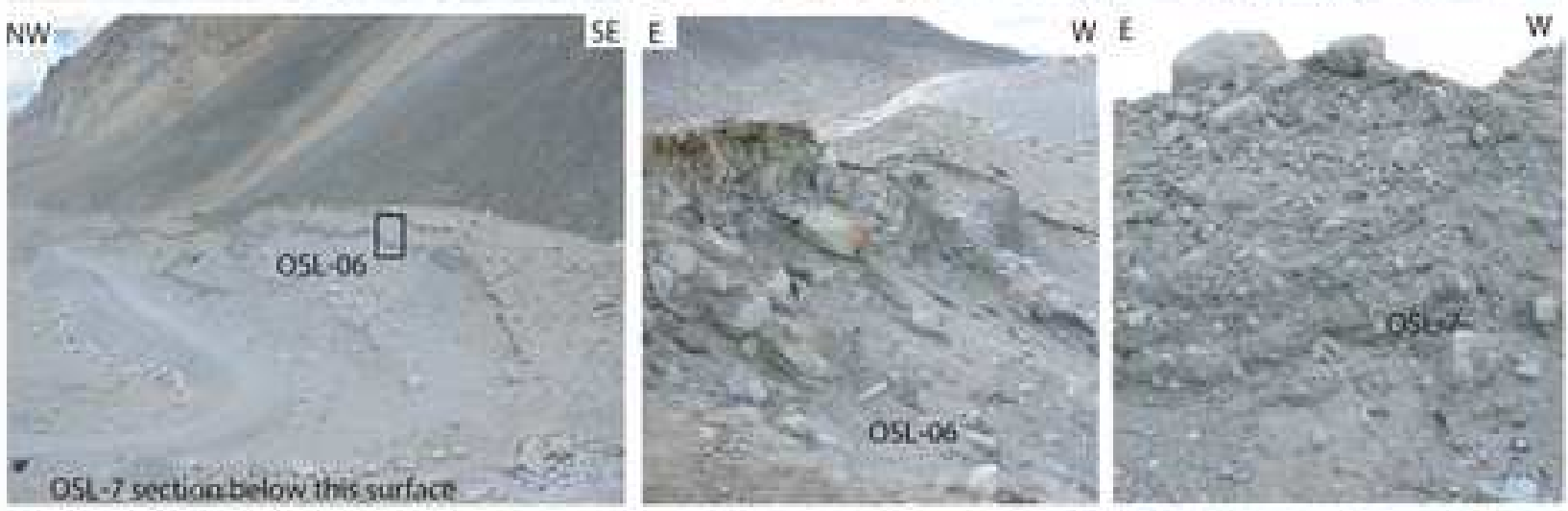

D
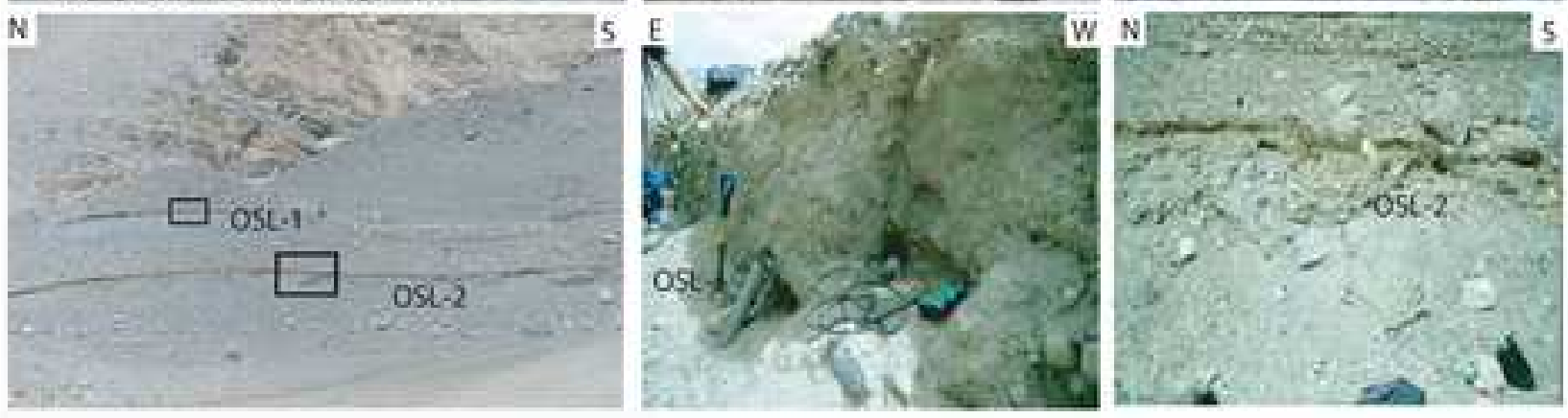

Figure 4 
Click here to download high resolution image
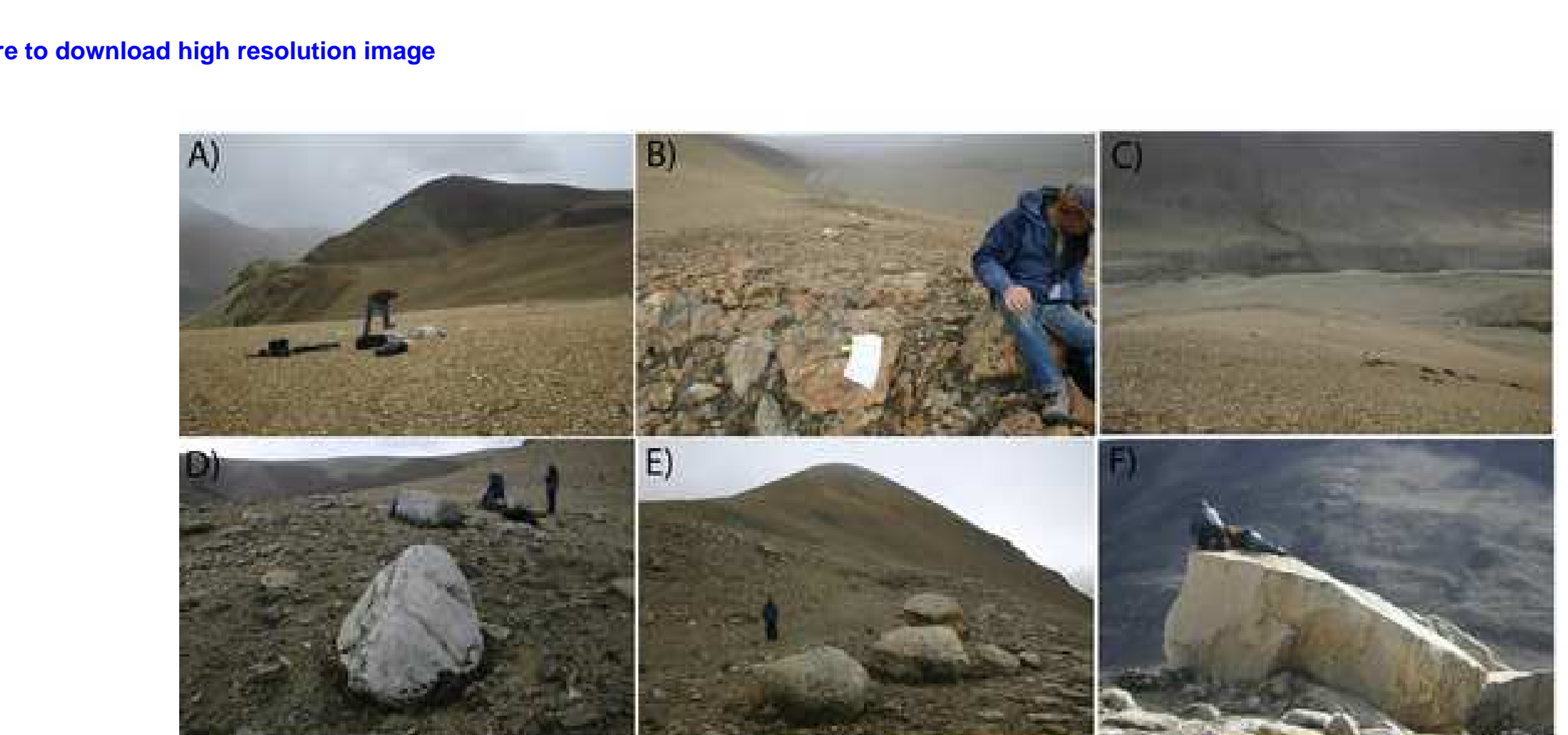

E)
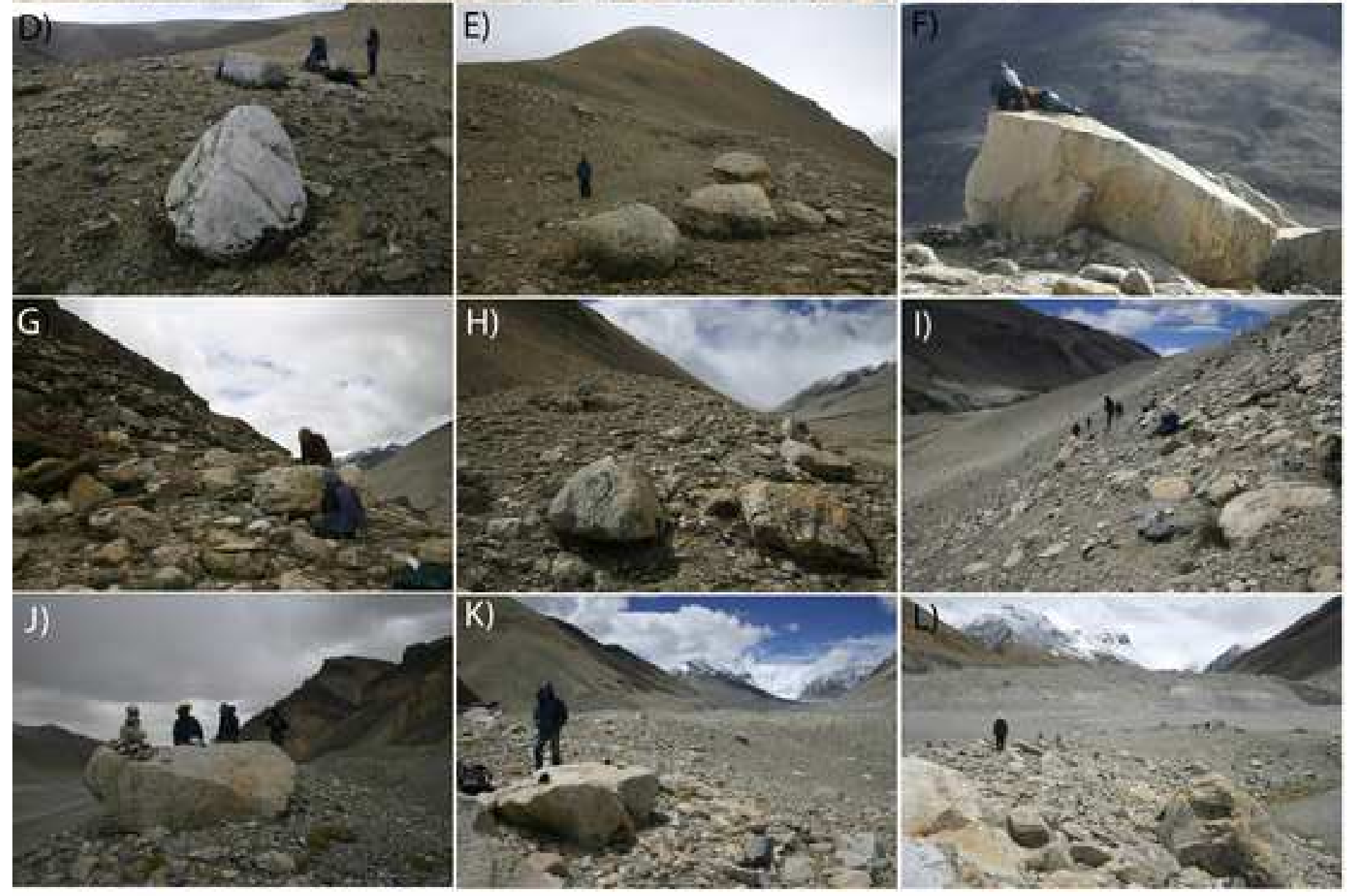

Figure 5

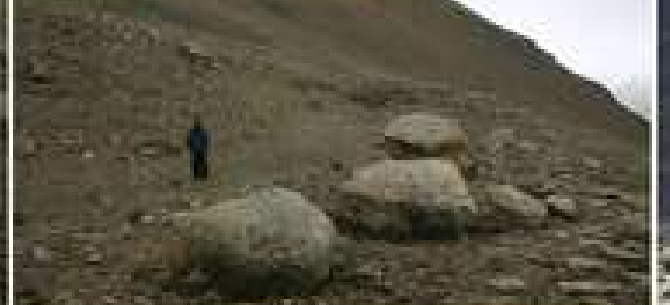

Figures

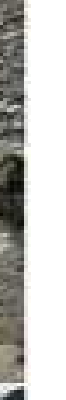


Click here to download high resolution image

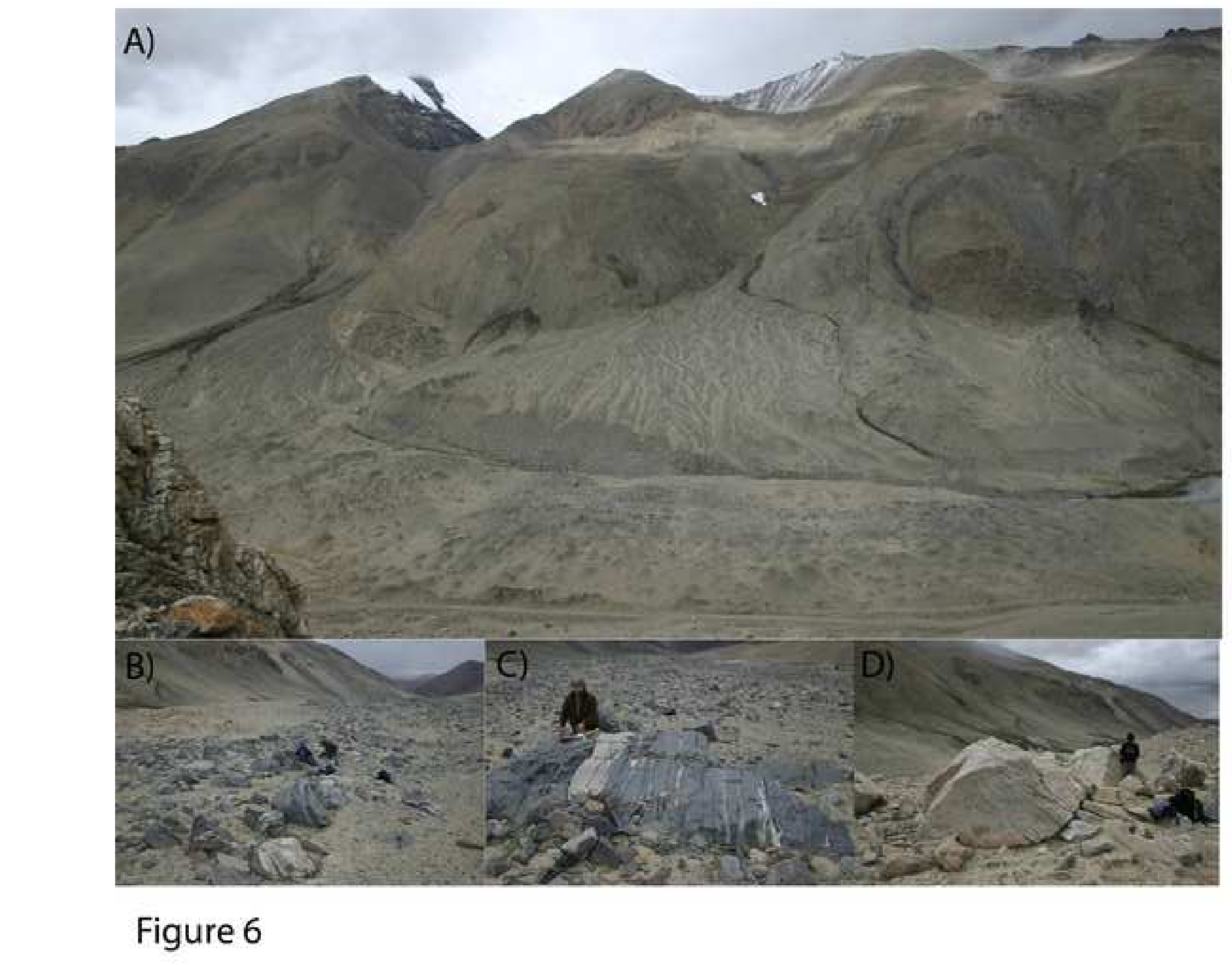

Figure 6

.

to download high resolution image
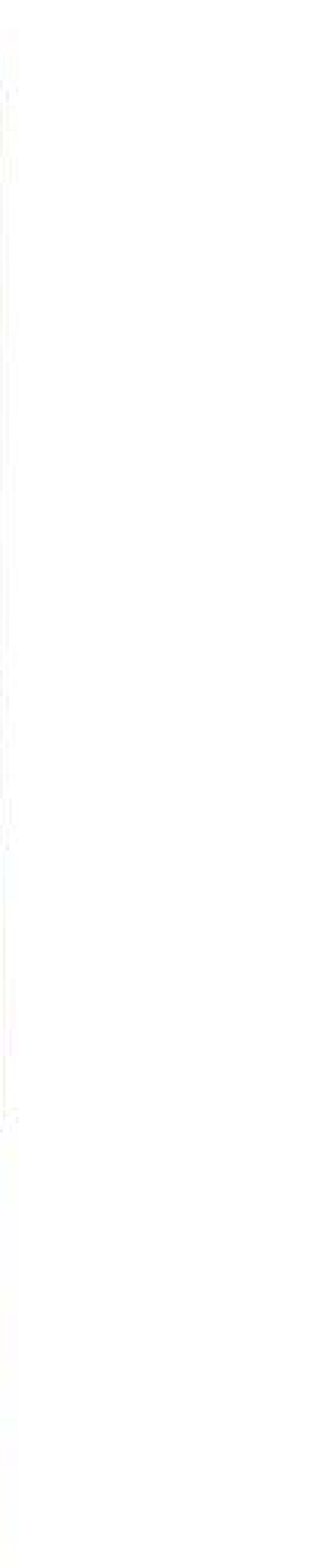

(

\begin{abstract}
Fire 6
\end{abstract}


Figure 8
Click here to download high resolution image

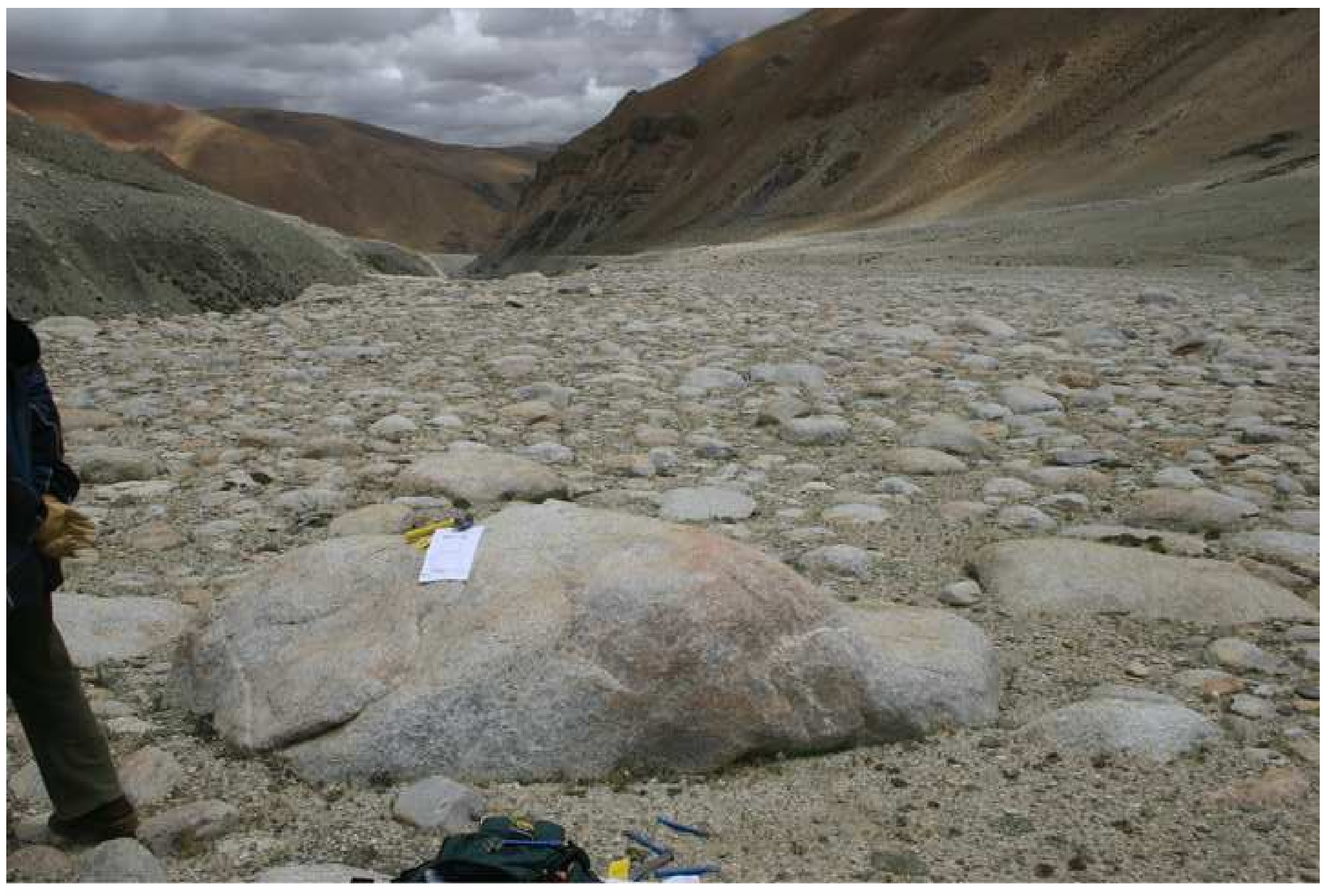

Figure 8

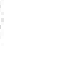

Figure 8

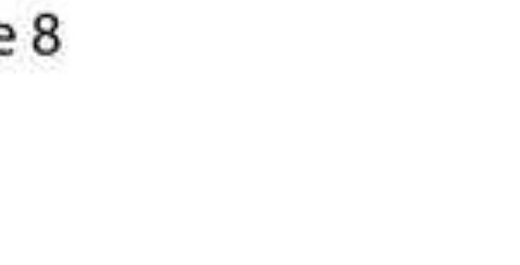




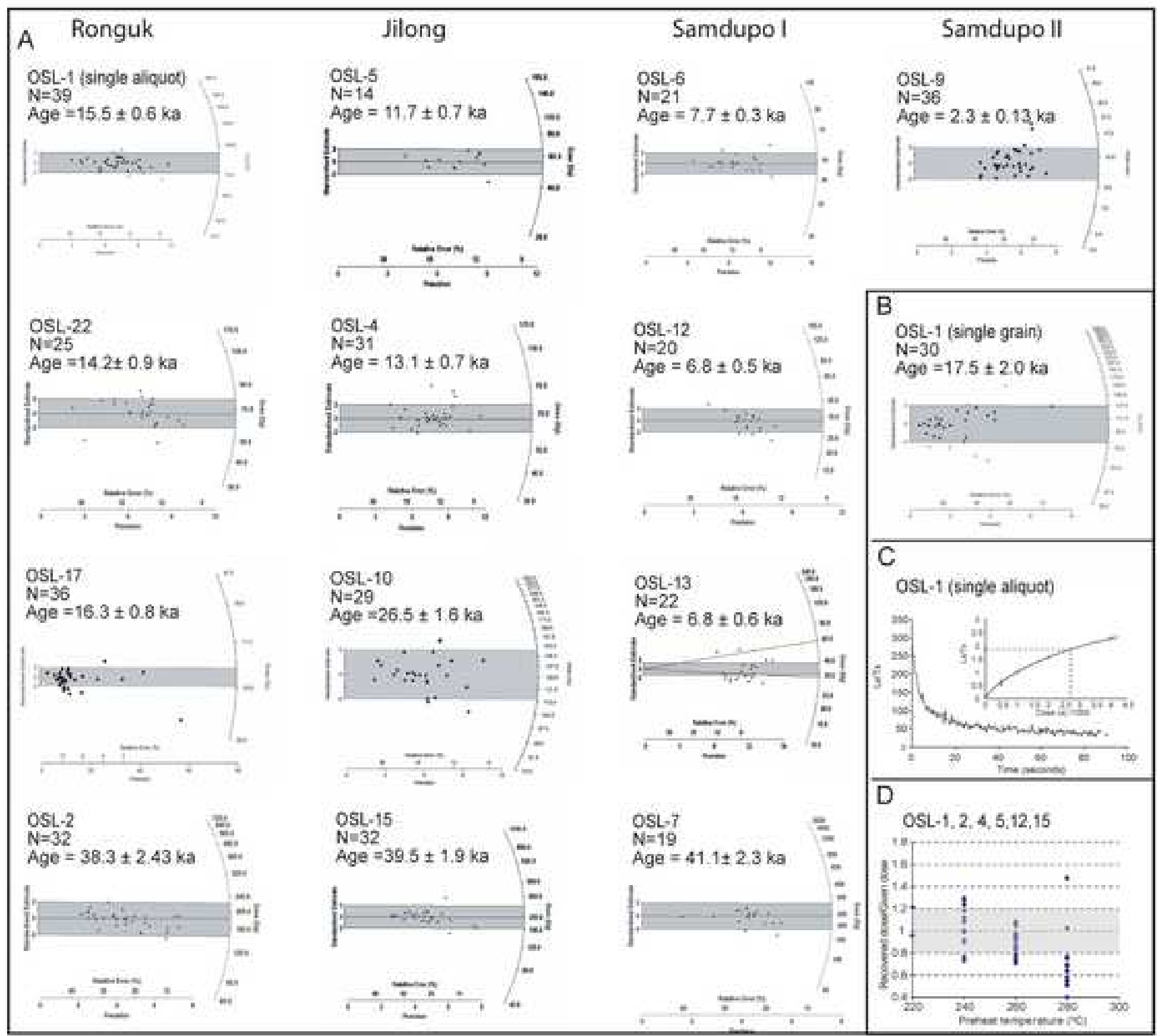

Figure 9 
Click here to download high resolution image

A)

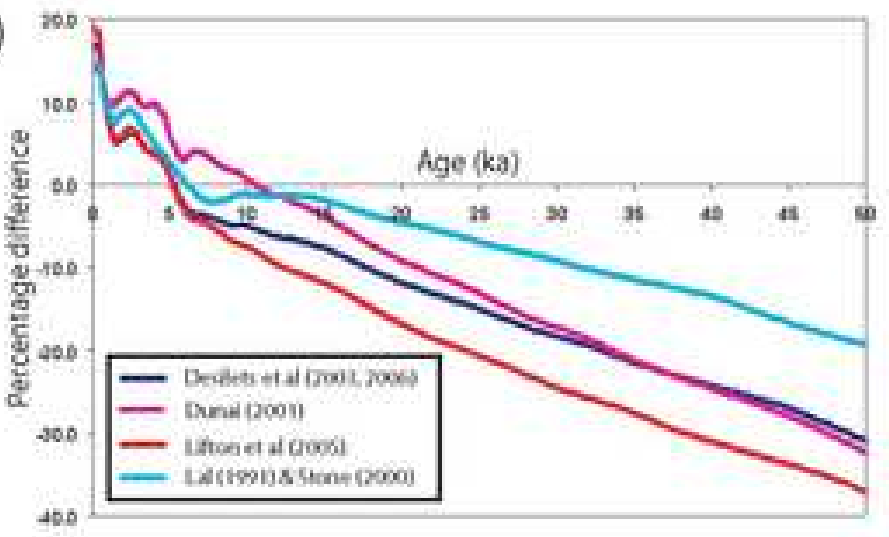

B)

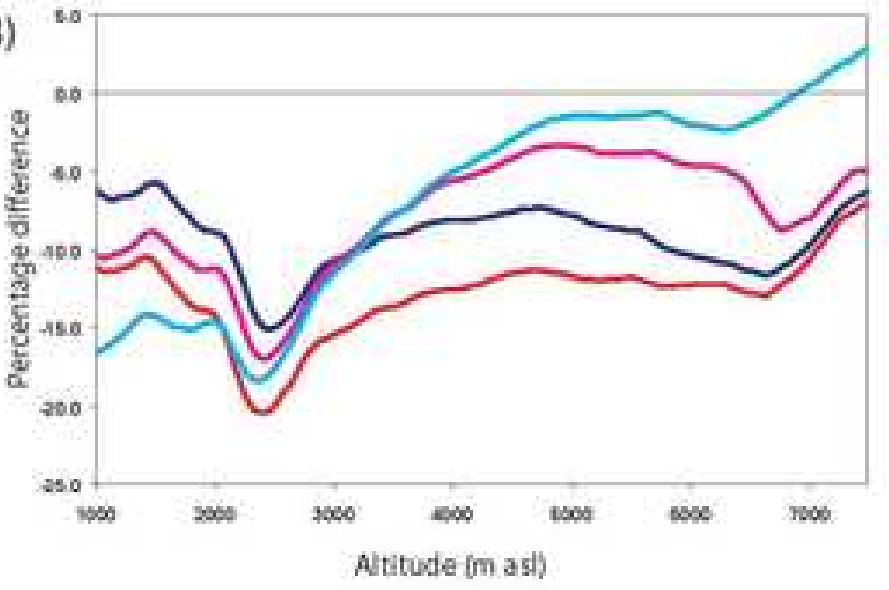

Figure 10 


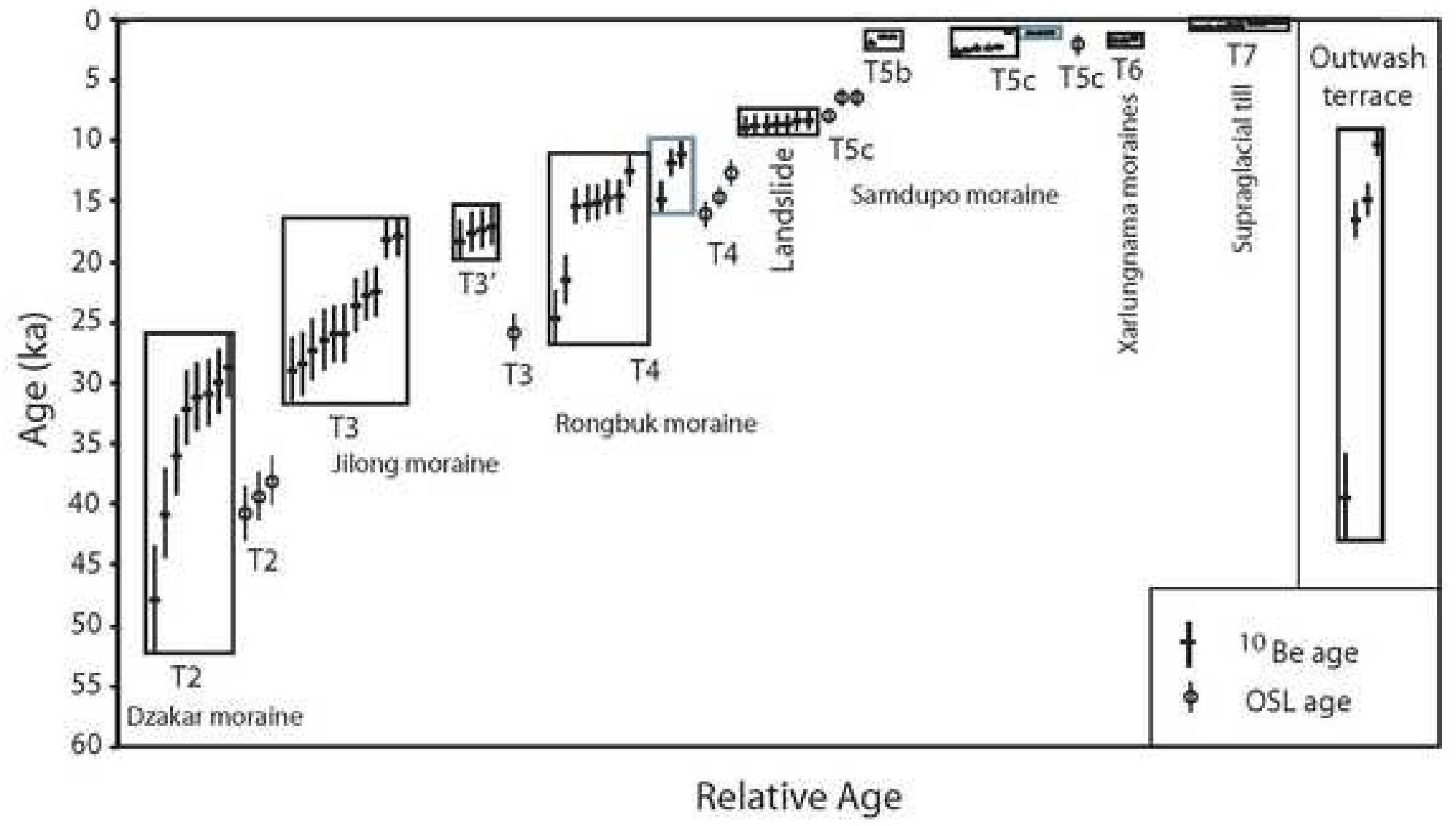

Figure 11 

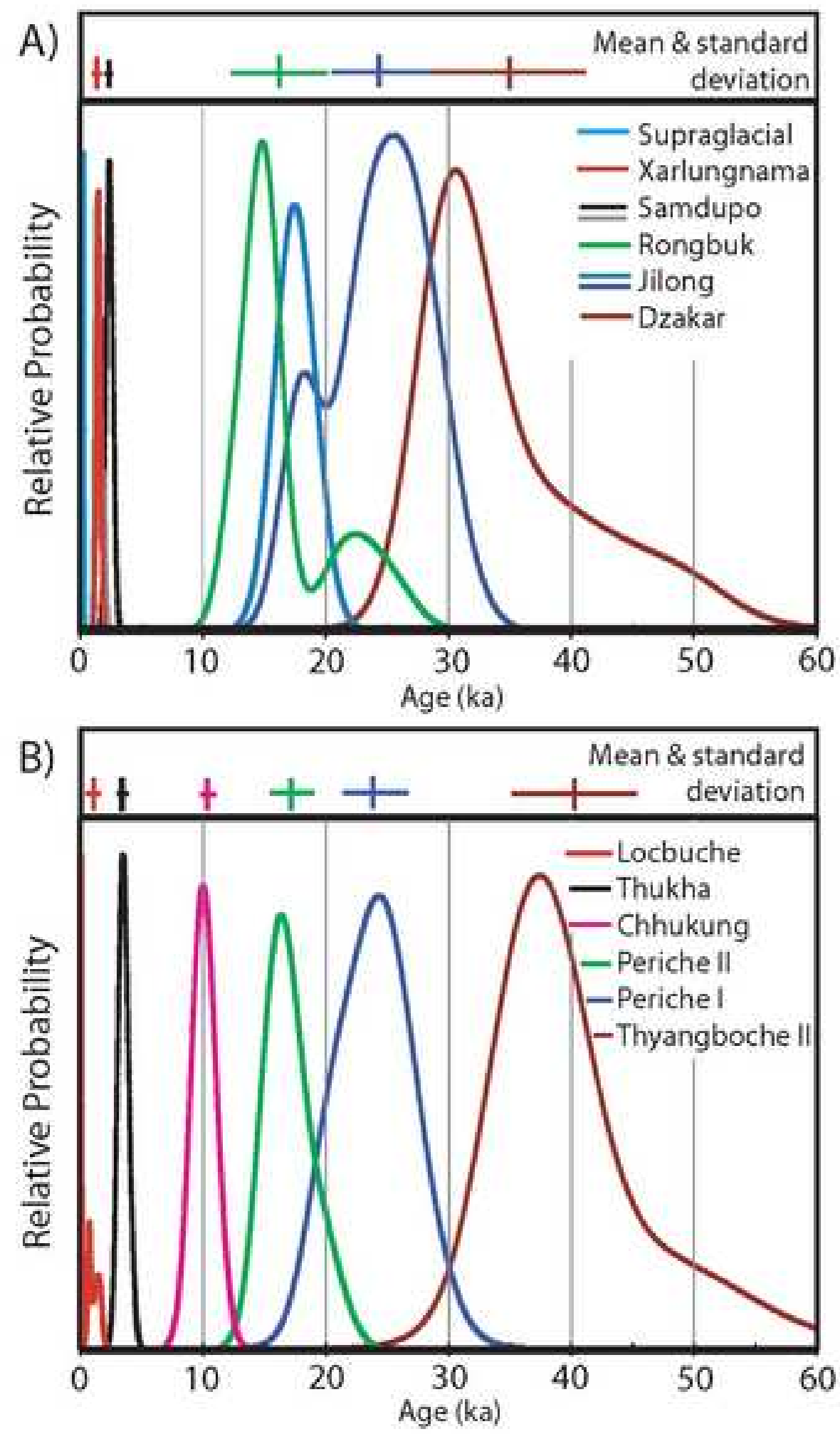

Figure 13 
Click here to download high resolution image
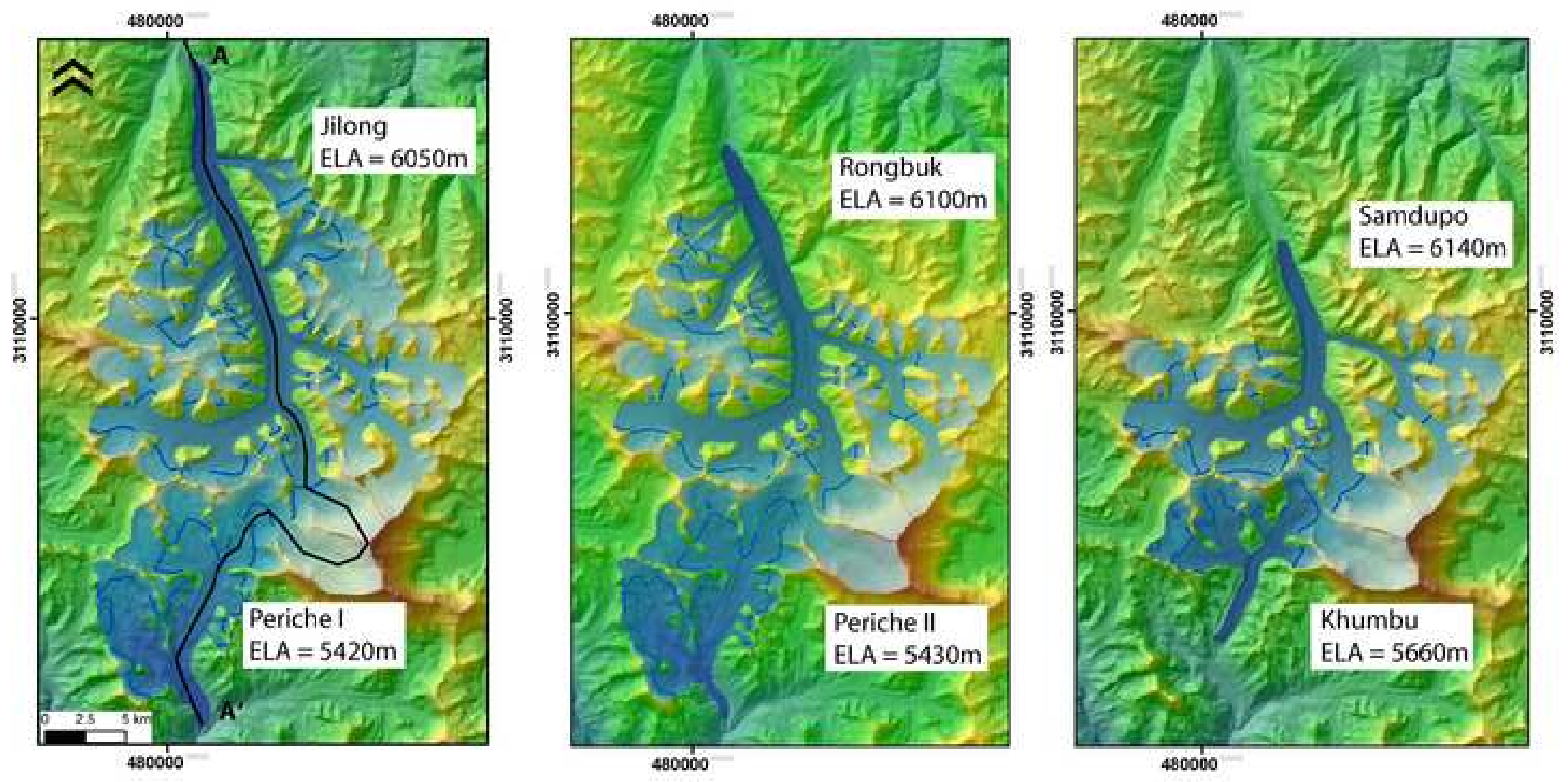

Figure 14 
Figure 15
Click here to download high resolution image

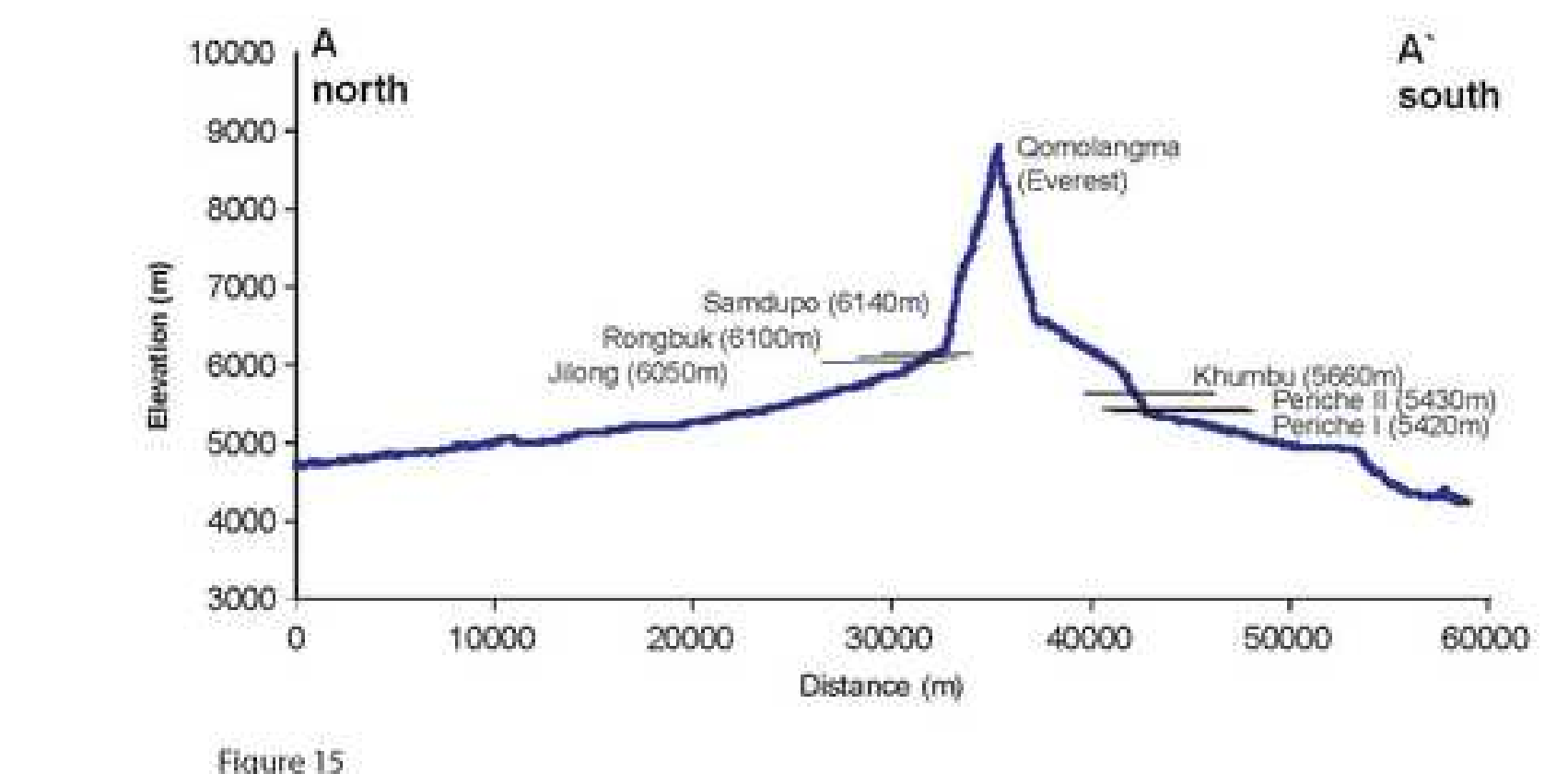

Figure 15

(1)

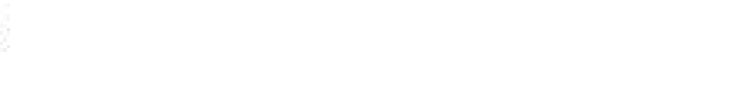

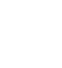

.

Pron 
Date Repository Item (Supplementary Data)
Click here to download Supplementary Data: Data Repository Item_Jan 30.doc

Clitis lick here to download Supplementary Data: Data Repository Item 30.doc

(n) (20) (n) (1)

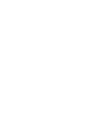

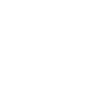

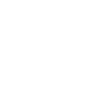
(1) (1) (1)

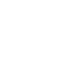
(1)

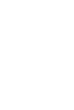
.

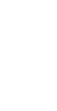

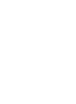

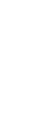
. $\sqrt{3}$ (1)

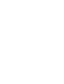

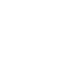
更

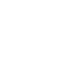

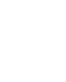
更

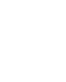
更

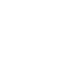
更 更

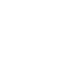

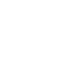

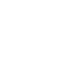

